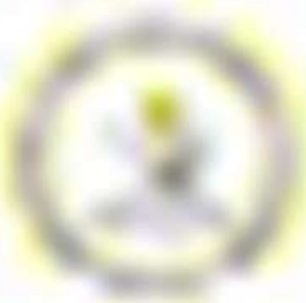

Kan bond of

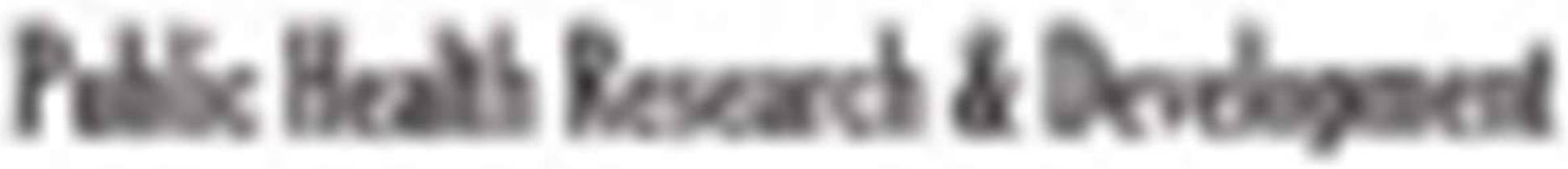

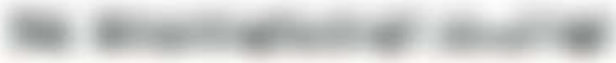

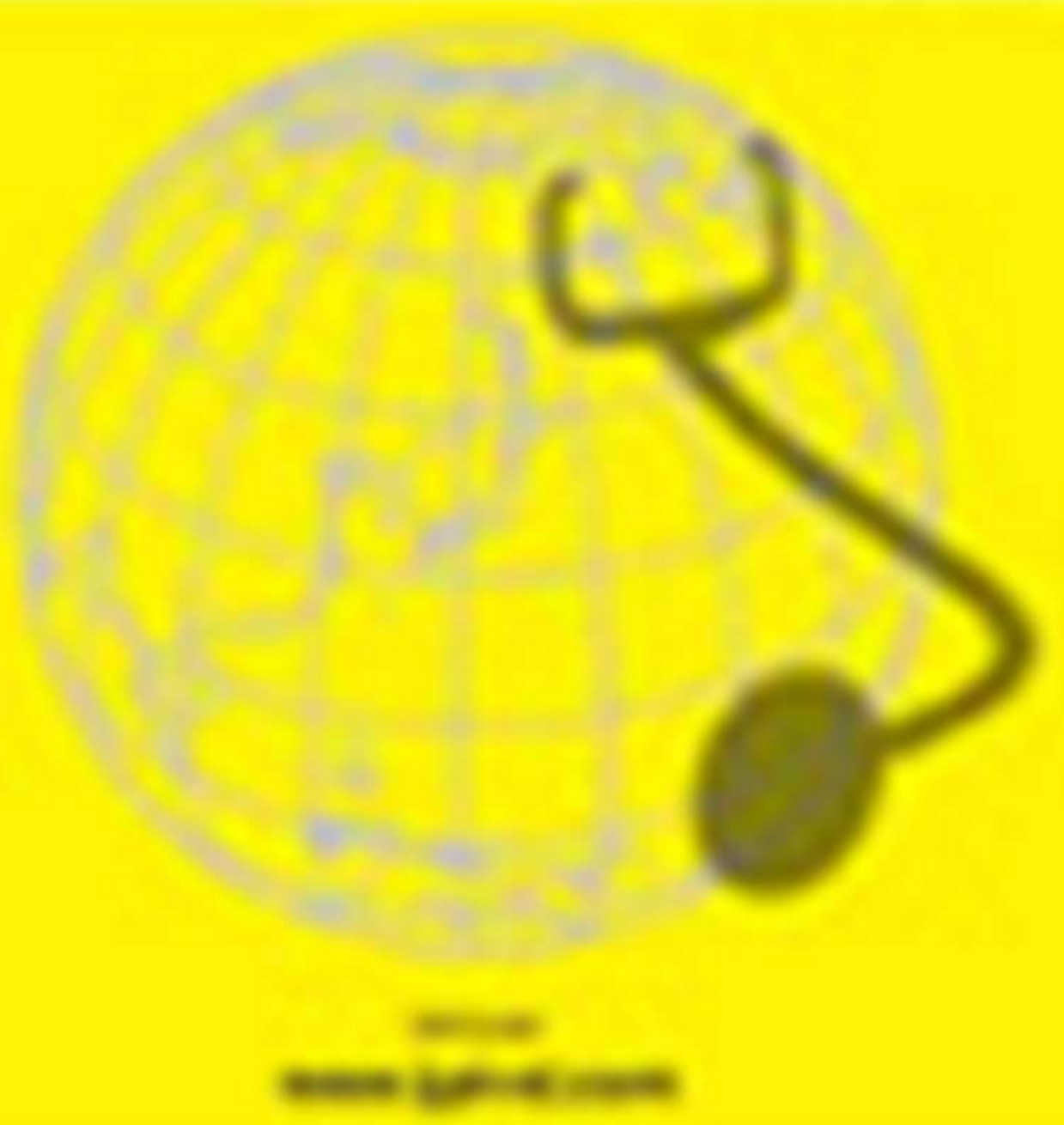


Prof RK Sharma

Dean (R\&D), Saraswath institute of Medica' Sciences, Hapur, UP, India

Formerily at Afl India insthute of Medical Soiences, NewDelhi

Email editorijiohrogmaricom

Associate Editor

Dr Manish Chaturvedi,

Associate Professor, Community Medicine

School of Medical Sciences \& Research,

Sharda University, Greater Noida

Assistant Editor

Dr Sonu Goel,

Assistant Professor.

Hospoltal Admintstration

Post Gaduate institute of

Medical Eduration \& Research,

Chandigarh

International Editorial Advisory Board

Dr Abdul Rashid Khan B. Md Jagar Din,

Assoclate Professor.

Assoclate Propson,

Penang Medical College, Penang.

Malaysia

Dr. Linah Askari, PhD,

Star Laureate 2000

Assistant Professar, Psychoology

Institute of Business Managemen

Cllfion, Karachi, Pakistan

Dr V Kumar,

Consulting Physician

Mount View Hospoltal,

Las Vegas, USA

Basheer A N-Sum,

Botany and Microbiology Dept't

college of Sclence,

King Saud University, Rlyaah.

Sendi Arabia

Kartavya J. Vyas,

Clinical Researcher

Department of Depioyment Health Research,

Naval Health Research Center.

San Diego, CA (USA)

Prof PK Pokharel,

Community Medicine,

BP Koirala instlute of Health Sciences,

Nepas

Dr Ch Vijay Kumar,

Psociate frutessor,

Dr Sunil Mehra,

Paediatrician \& Executive Director

MAMTA Heath insthute of

University of Buraimi Oman

Mother \& Child New Deihi

\section{Dr VMC Ramaswarmy.}

Sentar Lecturer,

Department of Patholiogy.

International Medical University

Bukit Jalit, Kuala Lumpur

National Editorial Board

Dr. Ranabir Pal,

Additional Protessor,

Community Medicine and Family Mediche

All india institure of Medical Sclences. Jodhpur

Prof. Sushanta Kumar Mishra

Community Medione

GSL Meớcal College - Rajatmundry,

Kamatakes

Prof D.K.Srivastava,

Medical Biochemistry

Jamia Handard Medical College,

New Deiki

Prof Bhavna Pant,

Community Medicine,

Subharti Medfical Colliege

$$
\text { Meerut }
$$

Prof M.Sriharibabu,

Generai Medione,

GSL Medical College, Rajahmundry,

Andhra Pradest

Prof Pankaj Datta,

Princlpal \& Prosthodentist.

Indracrastha Dental College

Ghaziabad

\section{Prof Samarendra Mahapatro, \\ Pediatrician, \\ Hi-Tech Medical Coliege, \\ Bhubaneswar, Orissa}

\section{Dr Abhiruchi Galhotra,}

Additional Protessor.

Community and Family Medicine,

All incial Institute of Medical Sciences,

Raipur

Prof Deepti Pruthvi,

Patholiagist:

Pathowagist,
SS institute of Medical Sclences \&

Research Center, Davangere,

Research

Prof GS Meena

Director Professor.

Maulana Azad Medfcal Callege

New Dein

Prof Pradeep Khanna,

Community Medicine.

Post Graduate instifute of

Medical Sciences, Rohtak

Haryana

Prof Jaya Chaturvedi,

Obstetrics \& Gmecology.

Himalayan institute of Medical Sciences

Dehradion

\section{Scientific Committee}

Dr. Ruchi Sogarwal,

Senior Technical Aovison-Program \&

Research,

MAMTA Heath instrtue for

Mother and Child,

New Deih

Dr Anju Ade,

Assodate Professor,

Navodaya Medical College.

Raichur, Kamatak.

Dr.E. Venkata Rao,

Associate Professor, Community Mediche.

Institute of Medical Sciences \&

SuM Hospltal Ghubaneswar

Orissa.

Titen

Pitu Goyal,

Associate Protessor, Anaesthesia,

Sarswathl /nstitute of Medical Sciences,

Panchshee/ Nagar

Dr. Anand Kalaskar,

Assodate Professar, Microbiobogy Prathima institute of Meokcal Sclences, $A P$

Dr.Md.Amirul Hassan,

Assoctate Professor, Community Medicine Govemment Medical College,

Ambedkar nagar, UP

Dr.N.Girish,

Associate Professor: 
Dr. Amit K. Singh,
Associate Professor, Commminity Medicine, Assodiate Professor, Commmunity Medidine Sitnagar - Ga trut uthege

Dr R G Viveki,

Assoclate Protessor, Community Mediche

Belgaum institute of

Medical Sciences, Belgaum

Karnataka

Dr. Santosh Kumar Mulage.

Assistant Professor, Anatomy.

Razhchur institute of

Medical Sclences RalchuriR/MS

Kamataka

Dr Gouri Ku. Padhy,

Associate Protessor.

Community and Family Medicine.

All inciali institufte of Medical Sciences,
Norobiology,

VIMSERC, Bangaione

\section{Dr BR Hungund,}

Assuciate Professor Pathology

JNMC, Bebaum.

Dr Sadhna Awasthi,

Associate Professor, Community Medicine

SDMT Medical College, Haldwan

Dr Shailendra Kumar,

Associate Professor, Communitis Medfóne

Medical College, Muzattemagar

Dr Rajib Roy,

Assistant Professor

Obstetrics \& Gynecology

ES/ Medical College, Kolkata 


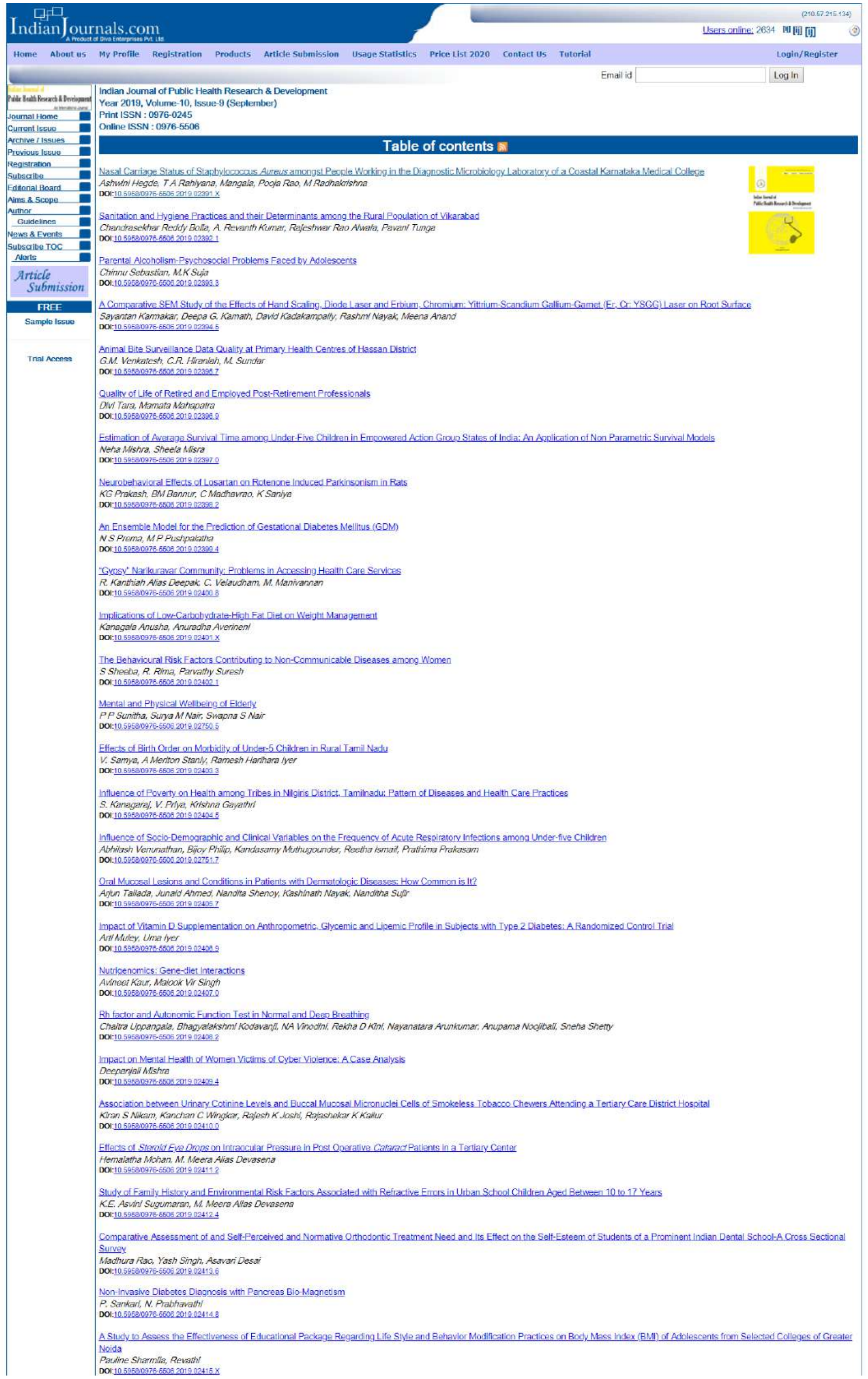


Impact of Market Economic Principles on Workplace Anxiety and Stress

P Pradees Menon, V Priva

DO: 10.50580976 .6506 .2010

Physiologic and Psvodokgic Understanding and Consideration in the Treatment of Geriatric Edentolous Patients-A Review
S. Pradeeg

DOI:-10 59580976-5505 2019 02117

Post Stroke Pain in Patients from Eastem Uttar Pradesh: A Prospective Study from a Tertiary Care Centre

Rameshwar Nath Chaurasia, Mtendra Sharma, Abnishek Pathak, Deepika. Joshl, Vijay Nath Mishra

DOI:-105958,0976-6606 201902418.5

Surgical Management of Radicular Cyst of Decidious Tooth-A Case Report

Rathanakumar Vigll Dev Asfr, Banu Sargunar, Rakesh Manan, Wasim Ahamed, Shanmugapniyan, Swama Priy

DOI: $1069520976-65002019024197$

Comparison of Perceptions Tovards Modifled PBL and Didactic Lecture among First Year Medical Students in India Ravindra Maradf, Chandana Bhargavi, KKishan, Krishnananda Piabhuvi, Vaideki Bvi, Prashianth N Dixitvi

DOl:10.5958.0976-5508 2019.02420

Teenager Response to the Conditions of Basic Level Emergency: A Phenomendocy Sturty

Ronal Surya Aditya, Fitriana Kumlasari Sollkhah, Setyo Budi Kum/awan

DOl:-10 59520976-5606 201902427

Development and Vaiclation of the Pre-Qperative Counselling Module for Total Laryingectomy-An Interprofessional Apcroach S Sheda, S Kiran, P B Anupama, R Balakrishnan, Venkataraja U Atthal, B Rajashekhar, Gagan Bajel

DOI: $1059520976-6506201902422$

Comparative Evaluation of Gallum Auminium Arsenide Laser in Disinfection of Root Canal System Shruthit H Altavar, Mithra N Hegde, Veena Shetty

DOI:10.5958.0976.6506 2018.02423.

Assessing the Awareness of Type 2 Diabetes Mellitus from KAP(Knowledge, Aftitude, Practice) Studes in West Bengal, India Sourav Gangopaathyay, Jayeeta Malumder, Anunangshu Girt

DOI: 10 59580976-6506 201902424

Cost Effective Solution for Visually Impaired

Sucha Senthilkumar, KBrindha, Angulakshimi, Kaaw'y

DOI-10 5952.0976-6500 201902425.

Avulsion Hilstological Perspectives and Storage Media-A Review

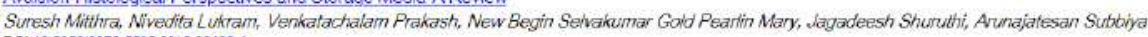
DO1:10.596e.6978.6506.2012.02420.4

Cost of Primary Care during Episodes of Child Dianhoea in Uttar Pradesh

AV Sura, Rahu' Sham

DOI:10 59580976-5506 201902427 .

Exploring Teachers' Perspectives on Mental Health Disorders-APreliminary Study

Vidya Prabhu, Lena Ashok, Veena G. Kamath, Asha Kamath, Varalakshmi Chandrasekara

DOI-10.5958.0976-6500 201902428

Relationship between Service Quality Dimensions and its Impact on Patients' Satisfaction: A Case Study of Jawaharlal Nehru Medical College Yogendra Pal Bharadw

DO105050078 6500201902420

Oral Health Considerations in an Achondionlastic Child: A Case Repor

Yogesh Chhaparwal, $R$ Vineetha, Keenthilatha M Pal, Shutha Chhacarwal

DO: $1059580976-5506201902430$ :

Firmicutes-The Lesser Known Flora Playing Greater Roles in Perindont tis

Anitha Balall, K. Mahalakshm!, Mahan Vallathan, Krishna Prasanth

DOt-1059520976-6506 2019024319

Parents Perception on General Anaesthesia in Paediatic Dentistry. A Questionnaire Study

P Anupama Navak, N Srikant, YM Kanuma, Kran N Bailga, Ashuin RaO

DOI-105050.0976-6506 201902432X

Correlation Between Auristic Endophenorypes and Assaciated Risk Factors

E. Chandrakala, KNagaraj

$059580976-5506201902433$

Femoral Tunnel and Lateral Femoral Condyle Measurements in Anterior Cruciate Ligament Reconsiruction

Diwa Sethl, Surendra U Kamath

Dol: 105 sent

Avocado Consumption and Immune Response: A Review on Ethigpian Context

Dher Garaf

DOI-10 5052:0976.6506 201002425

Evaluation of Immunostimulant and Chemprotective Activity of Chicoreus Ramosus against Cisplatn Induced Toxidiy in Baib/C Mice J. Bindhu, Arunava Das

DOI:-10.59520976-6509 2019024327

Quality of Life and Depression in Obese

KTMOIy, Shallya Shajan, Soniya johny

DOI: $1069590976-5606201902437$

The Effect of Enzymatic Denture Cleanser on the Physical Properties of Different Types of Denture Base Resin Materials Khushboo Singh, S Pradeep, Dhanasekar Balkrishanan, Aparna I Narayama

DOI:10.5950.0976-6506 201902420

Life and Social Exclusion of the Third Genders: An Ovenview from Malabar Reglon in Kerala State

Leena Chandran, M.K Suja

DO1:10.59520076-6506.2019.02429

Hentification and Aralysis of 1 Svndrome Features in Patients with Mental Retardation

Madhan Stinivasamurthy. Nagara/ Kakanahall'

DOF:10 59580976-5506 2019 02440

Adeption of Telemedicine among Dental Healthcare Professional

Preetf Y Shadangi, Manorantan Dash, Prof. Ayasakanta Mohanty, hyot Ranjan Das, Sunil Kar, Bibhuti Bhusan Mishra

DOI-10 59520976-6506 201902441

An Empirical Study on Association of Qperational Efficlency and Customer Satisfaction in Tertiary Hospitals in Punjab

Pritpal Singh, Mond Faman, Mahammad Ast

DOI:10.50520978.6506.2012.02442.2

Determinants of Food Choice in a Sctiod Environmen

Rashmi Bhatt Jagmeet Madan. Panchall Moitra

DOl:-10 59580976-5506 201902449

Assessing the Future Assessors: A Health Literacy Assessment Using the Nevest Vital Sign

Rathnokar P Unval, Priyanka Kamath, Medha Unval, Kashivi Gupta, Ashuin Kamath

DOI-1059580976-6506 2019024446

The Cost of Falls among the Elclerly in Kattankulathur Block. Tamil Nadu

Roshin' Mary Peter, Alex Joseph, KR. John

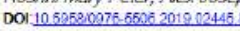

Varlation in Lip Thickness in Individuals vith Angle's Class 1, Class II and Class III Malocclusion-A Cephalometric Study.

S. Subashree Rathi. Arvind Sivakumar 
A Cross Sectional Study on Factors Influencing the Delay in Cinical Diagnosis in a Super Specially Eye Hospital Sachin Suresh Shinde, Woshore Babu Marvina, Madhavi Latha, Sukesh Krishna Chaitanya Lok DOR:1059830978-6506 201902447.

Impact of Power and Politics on Employee's Health and Performance in Private Nursing Homes of West Bengal. India: An Empirical Study Using Structural Equation Modelling.SEEM) Satakshi Chatterlee, Arunangshu Glyt, Pradip Pai DOl-105950.0978-550

Apolication of Laser in Carles Diagnosis and Inhibition-An Invivo Study.

Sonali Sharma, Sanjay M Londhe, Mithra N Hegde, Vandana Sadananda

DOl:10.59580976.5506.2019:02448 5

Iooth Brushing in Pre-school Children: An Indian Perspective of Parental Challenges

Sonja Sivadas, Ashwin Rao, Arath/ Rao, IM Karuna, Anupama Nayak

DOI:-10 59580976-5506 201902450 1

Clinicomicrobiological Insight into Bacteremia due to Gram Positive Cecci

Soumva Shrigin', Sevitha Bhat, KArchana Bhat

DOI: $1059500976-66062019024513$

A Study on Cost Minimization in Operating Room; Through Team Leaming at Tertiary Care Hospital of South Indla

T. Bharath

DOI:10.5058.0976-6506.2012.02452.5

Oral Health Education intervention among Preschoolers: A Randomized Controlled Trial

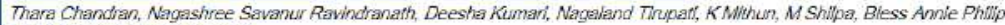

DOI-10 5952,0976-5600 2019024537

A Pooulation Based Study on 'At-Risk' Under 5 Children in Rural South-India

V. Samya, A Menton Stani, Ramesh Hanitara lyer

DOI:10.6058.0976-6506.2019.02454:

Friction Fit Implant Supported Removable Prosthesis

Kignesh Kamath, Shruthi Rao, Avjun Hegie

DOI:10.59580978 65082.2010 .02455$.

Analyses of Subject Wellbeing on Exercising Men. Women Students and Sedentary Men, Women Student

W. Vinu, A. Avin Mozhi

DOI:-1059520976-65062001902456 -

Knowiedge. Attitude and Practices Towards Household Solid Waste Management among Semi-Urban Residents-A Community based Cross Sectional Study from Southem Part of Caastal Kamataka, India

KEshwar, Ranjitha S Shetty, D Akhila, Bewlah Sarah James, Akhilesh Kumar Pandey

DOI:10.5958.0976-5506 201902457.4

Awareness Reglanding Preconcegtion Care among Women in Reproductive Age Groun

L Sunila, Lekho Visuanath, T Anju Philip

DOI:10 59530976-0506 2019024596

A Comparative Study on Health Profle and Health Seeking Behaviour of the Elderly in Urban and Rural Areas of Bangalore, Karnataka GV Akila, BA Awind, Avinan isac

DO1:10.59620976.6506.2012.02450.8

Effectiveness of a Parent Education Programme on Quallty of Life of Children with Epilepsy.

KP Anila Rajee Reghwnath

DO1:10.59580976-5506.2019.02460.

Mocelling the Factars Responsible for Better Health Service Quality. Perception of Service Providers

Meenaksh' Sood, Bunty Shama, Sahll Gupta, Shuchi Dawra, Chanchal Kaushik

DOI: $1059520976-5506201902451$

Effectiveness of Prenatal Classes During Third Trimester to Reduce Anxlety Level and to Improve Birth-Preparedness amona Primigravid Women Divya Bhadran, Anusuya. V. Prabhu, Lathra Alma vuliet

DOl:10.59600978-6506.2019.02482:

Knowledge, Atltude, Practice and Barriers for Self-care among Iype 2 Diabetes Mellitus Patients in Rural Tamil Nadu

Aliya Jasmine, Ramesh Harthara lye

DO1:10.59580976-5500 2019:02453.

Health Status of the Rabha Community: A Study in Gaalpara District of Assam

Bhargab Das

DOI:-10 59580976-5506 2019 02454

Acoustic Analysis of infant cry Using Multidimensional Voice Program-A Preliminary Study.

Deepa N Devadiga, T Remyasree, Alswarya Lli Varghese, T Ananthakristm

DOl-10.59520976-6506 2019.02465

An Analysis of Access to Primary Health care Services: A Study in Jorhat District of Assam

Samourna khound

DOI:10.59580978-5506.2019.02408.5

Adantive Sional Enhancement in clinical cardiac care Systems Using Normalized Median LMS Variants

Asiya Suthana, Mo. Zia-Uir Rahman

DOI:10 59580976-5506 201902457

A Health Status of Assam: A District Level Analysis

Bhargab Das

DOI:1059580976-6506 2019 02469

A Review of the Perception of Healthcare Quality among Patients and Employees

Bïlo Mathew, Raja Narayanan, Amit Mittal

DOl:10.59580976-6500 201902409:0

Experience of Sore Nipple and the Remedles Used among Postnatal Mothers

Janet Prameela D'Souza, Shobha Kamath. Elsa Sanatombi Dev'

DOi:10.5958:09765506 201902470 .

Prevalence of insomnia, and Slepe Hygiene Terhniques Practiced among Flderly Residing in Seledtert Odd Age Homes of Udupi and Dakshina Kannada District, Kamataka Laxminarayan Iver, Reniulai Yesooharan, Asha K Novak

DOI:10.5952.0976-5576 2019 024719

Maternal Risk Factors and Demographic Profile of Neonates Presenting with Persistent Pulmonary Hygentension in a Tertiary care Hospital, Odisha

Santosh Kumar Panda, Manas Kumar Nayak, Soumini Rath, Nümal Kumbar Mavakud, Subhra Snigdha Panda

DOI:10.59520270.6606.2019.02472.

Awareness of cancer and its Symptoms among the Rural Population

S Kalyan Ram, Muthwakshmi Muthiah

DOl:10.5958.0976-5506 201902473

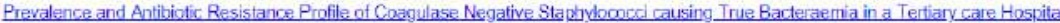

Nipa Singh, Srotaswinh Hota, Subhra Singoha Panda, Diptl Patunalk, Ashok Praharaj, Jagadananda Jene

DOI:10 59580976-6506 201902474.

Avallability of Manpower Faclities in the Health Sector of Assam

Raju Saikia

DOI:10.59620976-65002012.024750

Screening Urinary Methylmalonic Acid by Thin Laver chromatography In children with Suspected Inborn Errors of Metabollsn

U Saritha Kamath, Nalini Bhaskaranand, Anjall Razo

DOI: 10.59580976 .5500 .2019 .02470 .8

Lifestyle Practices and Clycemic control among Ivpe 2 Diabetic Patients in North Kerala 
Determinants of Satisfaction Level of Medical Tourists with Reference to Healthcare inclustryin Tamil Nadu india: An Empirical Study Arunangshu Girl, Satakshi chatteryee, Smita chakraborty, Abantl Aich, Swatee Biswas

DOI-10.50520976.6506.2019.02478.

To Evaluate and compare the Microieakage in class Five Cavitles Restored by a Nanohybrid and a Nanofilled Composite Resin by Dye Penetration Method-An in Vitro Study Chitharanjan Sheify, Namvata Khannia, Mithra N. Hegue

DOl:10.5958.0978 5508.2012 .02472$.

A Clinical Investigation onto the Effect of Occlusal interferences \& cognitive Behavioural Theragxin Temparomandibular Disorder Patients Vina/ Barochia, Vignesh Kamath, Konark Patil, Roseline Meshrankar

DOE:10 59580976-5506 201902754

Endodontic Management of Maxillary First Molar with Six canal s-A case Report

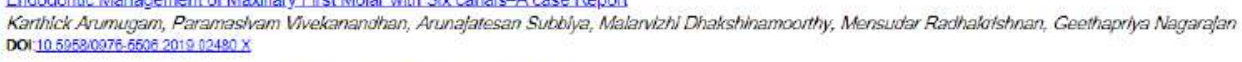

A Study on issues on Environment Pollution and Health Hazard in Tamilnadu

R. Bright Reginald Raja, S. Antony Sel

DOI:10.59580976-6500.201902481:

Determination of Bacterial contamination from Well wate

Rashmi Saliyan, Kusumakshi Naya

DOI:10.5958.0976.5506.2019.02432

Study of Orthophosphate, Pyrophosphate. Pyophosphatase and citric. Acid in Saliva With Reference to calculus Formation and Inhibition Rathinavelu Ganesan, J. Bhaskar, Kadhiresan Rathinasamy, Armmozhi Uaganathan, Mohan Valiathan DOI: $10.5952 .0976-55062019024905$

Potential Protective Role of Beta carotene on cadmlum induced Brain and Kdney Damage

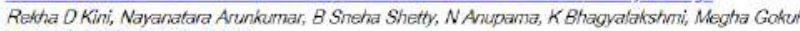
DOI-1059520976-5500 2019024947

Prevalence of Bacterial Vaginosis among. Antenatal Women Attending to a Tertiary care Hospital

Roshini Gundapanent, Ravindrandth Gundapanent, K. V. S. Plasad, Banerfi Neerugatti

DOI: $10.59580976-5506201902485$ e

A Preliminary Stutvon Prevalence of cartain Risk Factors for Non-communicatle Diseases in a Rural Population of Karnataka india

KSachidananda, Nanjesh Kumar, Shahul Hammed, P Kurv/kar, D Ullal Sheetal

DOI:1059580976-5506 2019 024360

Perspectives on Mental and Physical Distress and School counselling Based interventions for Sexually Abused Adolescents

M. Saheena, M.K. Suja

DOI:10.595200978-6506.20120.024272

Assessment of Oral Health Status and comparative Evaluation of Different Merhods of Oral Health Education in Children with Special Health care Needs

A. Supriya, Rekha Shenoy, Fraveen uodalli, Laxminarayan Sonde, invan Pashia

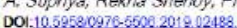

Evaluation of the Baby Filendly Hospltal initiative Programme in Two Hospitals Designated "Baby-Filendly" in Kirkuk cly, Ira

Fakher Abohaker Ahmed Gill, Dale Spence, Linda Johnston. Finoa Lynn, Richand Tutoman, Ziaj Mohammad Sadiq

DOI:10 59580976-5506 2019024896

The Combinatory the Effect of Healthy Ecucational Programs with Kinect Simulation Device on Leaning Some of Baskethall Skllls

Mahammed Shihab Akmed, Mayvadah Khald Jasim

DOI:-10 5952:0976-6509 201902400

The impect of Healith Awareness campaigns to Quit Smoking. (A case Stuoy in Amman city)

Rudaina Othrnan Yousi

DOI:10.5958:0976-5500.2012.02491

Active Ocular involvement in Iragi Patients with Behcet's Disease

Yaser A.R. Nasser, Riyam Faihan Rashid, Dina Shakir Yasiy. Mohammed Hadi Menshed AV-Osami, Faiq in Gorial

DOI:10.59580976-5506.2019.02492.6

Effect of Using Simulation (Electronic Media) in Learning of Some Basic Skills in Technical Gymnastic for 2nd Grade's Female Students

Abeer All Hurssein, Bashaer Hashim Abdul-Wahtd, Nidhal Obald Hamzeh

DOI:10.5050:0976.6506 2019.024938

Body image and Physical Perception of children with Preoccious Puberty in Baghdad city

Adraa Hussein Shawn, Eqbal Ghanim A/

DOI:10.5960.0970.6606.2018.02494.8

Health Workers Roles as Healthy Model: concept and instrument Develoging

Agustina Arundina Triharja Tejoyuwono, Lely Lusmilasari. Toto Sudargo

DOI:10.59580976 $=55062019.02495$.

Assessment of Serum Glucose and its correlation with the Pregnancy

Alaa Lmran Muse

DOI $10595 \% 0976-56002019024963$

Quilding and Applying the Personal Valuos Monsuro for the Ndministrators of Spors clubs and clubs for Poople with Discbilitics from the Point of Vlew of the Playors of Some Cames Amal Adulameer Tuama, Methaag Ghazi

DOI:10.59580976.6506 2019.02497.

Qualitative Study of Family Planning.(KB) Village Program's implementation in East Java Province-Indonesia

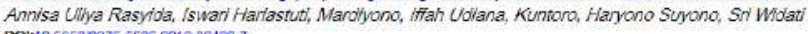

DOI:10 59580976-5506 2019 02499

Model of Peer intervention Assessment of Nutritional Educator in the Efforts to Change Behaviour in Decreasing Overwejglt in integrated islamic Elementary Schools at Makassar

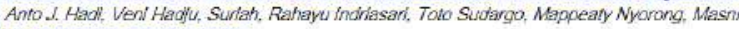
DOl-105950.0976-6506 2019024998

Association between Matemal iron and Vitamin D with Risky Development of Autistic childre

Ashraf M Osman, Hanan M Kanel, Emad A Abdel-Naen, Aliaa M Hilgazi, Noha Mahnoud Abdullah

DOI:10.5958:0976-5506 2019.025002

Incidence and Risk Factors of Hyocalcaemia in Post Thyoidectomy Patients in Tikit Teaching Hosplial

Ayouib M. Zedan

DOI-10 59580976-5506 2019025014

The correlation between Knowledge and Exoerience of Nurses toward Triage Decision Making at Lombok Nusa Tenggara Barat

Baiq Fitrihan Rukmana, Ahsan, Kiswantoro Rusca Putra

DOF-10 $59620976-65062019026025$

Detection of mecAGene in Methicillin-Resistant Staghwiococcus hemoluticus isolated from Blond cultures of Neonates in Baghdar

Butheina Mahamed Taka, Nadheema Hamnuod Hussein, Khetam H. Rasod, Sara Ali Jasem Malliki, Jumaah Dakel Hussein

Oko Mama culture Betel Nut consuming Habit in Kupang District and its Effect toward Sallvary Ph and Flow Rate

Christina Ngadilah, N. Hari Basuki. T. Rika Subamiati

DOt-10 59580976-5506 201902504

Determination Safe Duration of Exposure to Benzene in Workers of Petrolium Processing industrial Laboratory in indonesia by Using Noael of White Mice (Rattus norvegizus Ermita Isnaeni Purri Susvant, Abdu' Rohim Tualeka, Pudll Rahmawatt, Syamsiar S Russeng. Atja Wahyu, Ahsan, Dewi Kartikasar'

DOI:10 $59580976-5606201902605$

Assessment the Relevance of Dental Aesthetic inclex. Smile and Desire for Orthodontic Treatment among iraqi Teenager

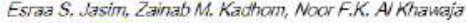

DOl:10.5958:0976-5600.2019.02500.3 
Effect of Thyroid Hormone Abnomalites on Hemoglobin Atc in Hemodialysis Patients Taking Erythropoletin Hanan L. Ak-Omary, Zainab M. Alawad, Buraq Hussenni

DO1-10.52520978 6500.2012025029

Efficacy of the Health Promotion Model-Based Intervention in Enhancing the Health Responsiblitivy of Middle School Female Suident: A Randomized controiled Tria Hiba Abdur-Waahid Damoud, Afifa Ridah Aziz

DOl:10.59590976-5506 2019.02510.5

Detection of Rotavinus Genotypes with conventional PcR in a Group of iragi ctiildren with Acute Viral Gastmenteritis

Hiba Sahah Jasim

DOI:-10 5958,0976-5506 2019 025117

Effect of Adding Medicinal Plant Excracts to The Broiler Diets on Productive Periormance Huda Q. AHHimdany, Fadhil R. Abbas, Ahmed A. Allaw

DO1:10.5952.0976.65002012.02512.

Structural Behavior Anailysis of Building Environment Automation System in Pharmaceutical industries

Jacky chin, Lin Shu-chiang, Sabtra Fadil Persada, llina Mufideh, Choesnul Jaquin

DOI:10.5958,0976-5506.201902513.

The impact of Radiation on Total Thrombocyte of Hospital Radialogy Workers in Kupano

Jannes Bastian Selly, Anoreas Umbu Roga, Noorce christiani Berek, Luht Putu Ruliaty, Jacob M. Ratu

DOI:1059580976-5506 201902514

Importance of collaborative intervention of Preconception Nutrition in Supressing the Stunting casse in East Nusa Tenggara, indonesia

Jeffrey Jap, Sri Sumami, Mroman Antra Damayant

DOI:-10 59520976-6506 201902515

Evaluation of Folic Acid content in the Pregnant Women

Jinan Hussein Mutlay

$001050520976-5096201902510$

Isolation, Identification and Antibiotic Susceptibility Testing of Bacterial Pathogens causing Seminal Fluid infection in Human Males Admilted to the infertility centers in Najaf Province Vinan Mohammed Hussein, Anaam Jawad Alabbasy, Suhair Abolukareem Al-Rammahi, Ahmed Abduthidha Ameen Shlash DOI:-10 59580976-5506 201902517

Conjecture of TSP concentration and PM. 10 through Measurement Dust Fall (Study of Dust Dispersion from Special Roads for coal Trans pert) Junaidi Rahmawat, Muhammad Pabruddin, Agnes T Dlana Nerawat

DOI:-10 5958,0976-5606 201902518 X

Development of cardlovascular complications in Polycythemia Vera Patients Influenced by Increased Blood Viscosity.

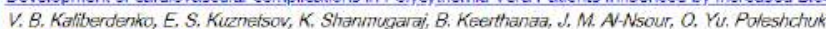

DO1:10.5950.0978-6500 2019.02519.1

Determination of Safe concentration of Benzene Exoosure in Workers in a Laboratory of Oll Processing industry in indonesta Kharina Almira Djalali, Aboul Rohim Tualeka, Pudil Rahmawati, Syamsiar S Russeng, Atjo Wahyu, Ahsan, Dewi Kartikasari

DOi:10.5958,0976-5056 2019:02520

Saponin Maintaining and Dose Determining in carica Panaval eaf conkies as a Breast Mik Booster (gahactogzoguea

Krisoliana Wilayanti, Hertanto W. Subagio, Martha irene Kartasurya, Sri Achadi Nugrahen

DOt:-10 59580976-5506 201902521X

Factors Related to competence in Prehospital care

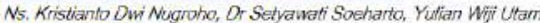

DOI:10.5962.0976.6506.2012.02522.

Emeowement of coastal communitles Through Systems Aoproach in the Field of Environmental Health in Kendari city. Southeast Sulawesi Province, Indonesia

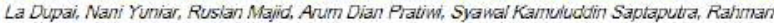

DOI: $10.59580976-5500.201902523$

Study the Level of interlukin-2 During and after Treatment in Soutum of irag Patients with Pulmonary Tubercalosis

Liga K. A. Alzubalibl, Nisreen Sherff Alyasiri, Luma yousif Mehof'

DOR:10 59580976-5506 2019 02524.5

Warm Footbath Minimize Ostheo-arthritis Joint Pain on the Elderiy in Surabaya's Public Health center

Muhamad ibnu Hasan, Elida Uiliana, Deni Yasmara

DOI:10.525e.0976-6506.2012.02526.7

An Epidemiological Study an common Types of Tuberculosis in A-Najaif cty

Muitadina M. Hameed, Alas S. Avattabi, Hassan M. Aboimaal't

DOI:10.59580978.5500. 2019.02520.

The Effect of Ammuntull Bj] aTlanang $\mathrm{Na}$ Beja-Beja Model on Knowedge, Motivation, and Altude of Pregnant Women's Health Services in Jeneronto District, indonesi Mustamin, Ridwan Amiruddisn, Sukri Palutturi, Stang, Risnah

DOl: $1059590976-5506201902527$.

A Study on New Frontier of integrative Medicine on Social Mecila with Special Reierence to chennal city

N. Manivannan, G. Mythili

DOI-10 5059:0076-6506 201902528

Implementation of Nutrition Education to Knowiedge. Behaviour, and Performance of Junior High School children

Nanik Suhariatio, Sri Handayani, Agatha Jumian

DOI-10.5958.0976-5500 2019.02529.4

11-18-137G/C(rs 187238) Gene Polymorphisms in Puimonary Tuberculosis iraol Arab Patients

Nawail Mohammed Utha

DO1:10.5958,0976.5506.2019.02530.0

Risk Factars Related to Diabetes Mellitus

Noor Diant, Dhian Rilin Lestar

DOI:1059580976-6506 201902531

Association of Hunting Behavior and Malaria indidence: A cross Sectional Study on Nuaulu Tribe community in Mesoendemic Avea of Malaria

Nur Baharia Marasabessy, Oedyjo Saedirham, Yoes Prijatha Dachlan

DOI:10.59520976-6500. 2012.02532

Determination of Ammonla Gas Safe concentration in chicken Farm Workers in Lembak Village. South Sumatra indonesla

Putri Arianto, Aboul Rohim Tualeka, Desheila Andarini, Pudji Rahmawati, Syamsiar S Russeng. Atjo Wahyu

DO1:10.5958.0976-5506.2019.02539.

Body image among Postnatal Primparous Women in Maternity Hospitals in Baghdad cily.

Ratah Raad Aboul-Salan, Suhad Hilkmat Khaint

DOI:10 59580976-5506 2019 02534

Role of Adropin in Women with Polycystic Ovary Syndrome

Rana AVi Hamdi, Hanan Naarna Abas, Fatin Abdu' Aziz Asaeed

DOI-10 50520097- 5500201902525

The Alooholic Extract of carrot (Davous carota L) Seeds as Antioxidant in Male Albino Mlce Treated with $\mathrm{H}_{2} \mathrm{O}$

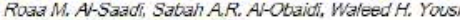

DO1:10.5958.0976-5506.2019.02530.1.

The Fthanolic Extract of Alwa Fruits inh bits Nephrotoxicivy and Deterioration of Some Biood Biochemical Properties induced by Gentamicin in Male Rats

Saher Mahmood wasd, Widan Kamal Noor, Bushra Aboas ALzubaild

DOI:10 59580976-5506 2019025373

Correlated Levels of Anti-Inflammatory Interfeukins ( $(\mathrm{L}-4$ and $\mathrm{IL}-10$ ) with Allercic coniunctivitis (Ac) in iraci Patlents 
Nithad knatave Tewoot Osam

DOI:10.52520976-6506.2018.02639.5

costal cartilage Graft combination with V-Y composite chondromucosal Advancement Flap for correction Unilateral deft Lip Nasal Deformity

All Adwal Ar, Yasir Naif Quassim

DOI-10.59580976.5506.2019.02539

Assessment of Barriers to implement Nursing Processes

Tameem Thamir Mayout, Ahmed Zuhair Abd AV-Qader, Mohammed Tariq, All

DOl-10 59590976-5506 201902540

The Effect of Life Skill Education on Cjgarette Control in Adolescents

Ulmar Daeng Paialla, Muhammad Syafar, Ridivan Amivudditn, indar, Ahmad Yan/

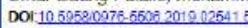

Effectiveness of an Educational Program on Women's Knowledge about Family Pianning at Primary Health care centers in Av-Diwanyah Covemorate Sajida Khamees Abdullah, Wissam Jahbar Kasim, Fatima H. Abbas, Eqbal GH. Màala

DO1-10.59580976-5500 2019.02542

Effects of Sugdementation of Thymus Vulgaris and Zingiber Officinal Pouder on Repreductive Performance of Ageing Broiler Breader Male Sameerah Hussein Amen, Rashid Hassan Hamld Al-Dalaw, A K shanoon

DOI: $1059690976-6506201902543$

Effects of Personality Type on Bumout in Korean Clinical Nurses: Focus on Personality Type D

Song Hye Suk, Lim So-Hee

DOI:10.5958:0978-5500.2019.02544

Correlation of Maternal Education with Parenting and child Nutritional Status

Sukmawati, Sirajudolin

DOI:10.59580976-5506.2019 02545:

Effectiveness of an Educational Program on Emergency Nurse's Knovdedge and Practice about Advance cardiac Life. Suppert at Emergency Medicine Defariment in Bagluxdad city Talib Kallfa Hassan Al-Temimi, Hussain hadi Atjla

DOL:-10 $69530976-6506201902545$

The impact of chess Games towards comtortableness of cognitive Mind on Eldedy

Wildan Agumg Wahyus Laksona, Joni Hianyanto, Khoridatud Bahilyah

DOl $1059590976-6606201902647$

Lighting and Nolse Levels in the Neonatal intensive care Unit (Nicl)

F. Sri Susilaningsih, Siti Yuyun Rahayu Fitri, Ai Marchiviah, Enmiati, Yanti Hermayant

DO1:10.5958.0976-5056 201902549.8

Psychological Treatment for Moior Depressive Disorder: Effectiveness of Cognitive Behavioural Therany,

Jirushlan Dorasamy

DOI:10 59590976-5506 2019 02549X

Vaive of Understanding Personality and Proactive coping for University Students

Mishilan Darasam

DOH-10 59520976-6506 2019 026506

Effectiveness of an Education Program on Nurse-midwives' Practices Related to Postpartum Hemorhage at Delivery Room of Matemity Hospilals in Baghdad cliy

Azhar Hussein Avi, Ezedeen F, Bahaldieen

DOI:10.5958.0978.5500. 2019.0255

Effects of Pain, Disability. Soctal Supact and Stress on Depression of community-dwelling Flders

DO-10 59520076-5506 201902552x

Psycholggical Analysis of customary Law as the Spirit for indigenous Pepple of Bengkulu city indonesia

Rangga Jayanuarto, Khudzaifan Omyatt, Absori Absori Natangsa Surbahti Fiviani Nur Oamayont'

DOI:10.5958.0976-6506 201902653 :

Com Silk Based Ethosomal Gel: A New Treatment for Perlodontitis in Diabetic Alino Rats a Prelimenary Study

1. E. Riewpassa, YR Kim, A N. A. Tenvilib, J. S. Untung, N. S. DJamaludir, MH Achmad

DOI-10.59580976-6500 2019.02554.3

Immunological Effect of Cepparisspinosa Extract and iraol Datos Vinegar in White Mice infected with PSeudomanas Apuragenos:

Asif Hasan Abutrazaq, Mayada Aboullah Shehan, Najeeb Mohammed Hussein, Mohammed. A. Hamad

DOl:10.5959,0976 5506201902555.5

The Correlation befween Interleukin-1 A and Bone Destruction on chronic Sugurative Oifis Medla with cholesteation:

Munammad Reza Mahardika, Artono

DOI: $10.595300976-56962019026567$

Effect of Alcoholic Extract of Opunta Ficus indica on Semen Quality of Awassi Rams after Different Cooling Periods

Abd AL-Kareen Abd AL-Reda Hobi, Ahmed Mahdi Abbas AL-Helal'

DO1:10.5250.0976-6600.2019.02557:

Motivation in Health Behaviour: Role of Autonomous and controlled Motivation

Adeline Y. L. Tam, Rohaizat Baharun, Zuraidah Sulaiman

DOI:10.5958.0976.5506.2019 02559.

The Effectiveness of Aluminum Potassium Sulfate Moso-Partides Addition into Soft Denture Lining Material on Canöida Abicans Arherence

All Mohad, Abdalbseet A Fatalla

DOI:1059580975-50506 2019 025

Nurse Feelings When Become a Member of code Blue Team at Wava Husada Hospital Kepanjen, Malang

Annisa Rahmania, indah Winarni, Septi Devi Rachmawati

DOI:10.59520978-6506.2012.02500.8

Determination of $\mathrm{XXc}_{\mathrm{L}} 12$ Serum Levels in Breast cancer Women

Ankan H. Fiayyeh, Ehab D. Salman, Alice K. Meloonian

DOI:10.59580976.5500.2019.02501.0

Relationship of Gestational Age. Folic Acid intake and Haemoglobin Level of Third-Trimester Pregrancy with infant Birth Weight in Ende Regency. East Nusa Tenggara Province. indonesia Asmuiyat Saleh, Harsono Sallimo, Endang Sut'sna Sulaeman

DO1:-10 59520976-5506 201902502 2

Effect of Latiobacilius on the Small intestinal Mucosa Measurement of Healthy Broi ers chicken Under Heat Stress condition Balques H. All

DOI-10 59530976-6506 2019026639

Bacterial contaminants Associated with Poultry Feeds

Bushre Mohamunad Kadhim, Haifa Nori Mater

DO1:10.5958.0976-6506.201:02564.

An Exploratory Study on the Roles of Bhutanese Primary Health care Managers in Resoonding to childhood Obesity Chimi Wangmo, Phucit Tejativadihana, Mary Cruickshank, David Briggs

DOI:-1059580976-5506 2019025058

Determination of Safe Benzene concentration at Kebon Jeruk Toll Gate Keeper Jakarta indonesia

Danang Setia Buol, Aboul Rohim Tualeka, PudJ Rahmawatl, Syamslar S Russeng, Bambang Wisorlyono

DO1:-10 695200976-5506 201902666 X

Analysis of Patient Safety culture and Worix Team in Ecucating the Effect of Leadership Style on Patients Safety Pefformance

Dike Widyakti Sawifina Maharani, Margono Selíawan, Dodi Wirawan hrawanto, Mintarti Rahayu

DOl:10.595800976.5500. 2019.02567

Matemal Dearh Model Decreases the Exoression of BDNF in Ramus Nanvegicus Newborns' cerebrum and carebellum

Duhita Dyah Aosari, Hemanto Thi Joewono, Wrijiati

DOI:10.59590976 5506201902503 : 
The Safe concentration Determination for Public Health Problems Due to inhalation of Ar containing Hydrogen Sulfide Around industrial Avea of Medan Indonesia

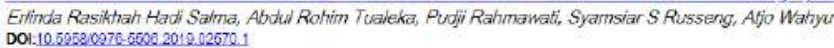

Biscuit Enriched with Billih Fish (Mystacoleucus-padangensis) increases cognitive in Experimental Rat

Fivi Melva Diana, Rimbawan Rimbawan, Evy Damayanthi, Mira Dewi, Vetnizah Juniantito, Nur indrawaty Lipoeto DOI:10.5959.0976-5506 201902570

Determination of Safe Duration of Expasure to Benzene al Public Gas Stations Avound Dixonegoro University Semarang, indonesia Genduk Lintang Rusmawarda, Abou Rohim Tualeka, Dimas Triyad, Pudji Rahmawat, Syamsiar S Russeng, Afjo Wahyu, Ahsan DOI:10 59580976-5506 2019 02572

Bacterial Uropathogens isolated from Akkaline Urine and their Susceptibility to Antimicrobial Agents

Ghoffan Fiasal, Abhas A. AVDullarni. Ali M. Jadfar, Abdullazak SH. Hiasall

DO1:10.6960.0976-6500 2012.02673.7

Aerabic and Anaerobic Bacteria in Tonsils of Different Ages with Recurrent Tonsillitis

Gubahiar F. Kajm, Siham Sh, AL-Salhi, Qanat Mahmood Alya, Kasim Sakran Abass

DOI:10.59580976.5500.2019.02574.9

Efficacy of the Heath Belief Model in Enhancing the Oral Health of Female Middle School Students

Halah Kama/ /smael. Aysin Kamal Mohammed Noori

DOI:10 $59580976-5506201902575$ ?

The Effect of Selection on Some of the Basic Determinants of Learning Some of the Basic Skills of Footbai

Hamid Aboul Shaheed Had, Hayder Jaber Mousa, All Hameed All, Hayder Nall Habash Aishaw'

DOl:10.5050.0976-6506.2012.02670.2

The Method of Leaming in order to be Able to Follow the cognitive Method (indenendence Versus Dependence on the cognitive Field) and its impact on Some Basic Sklls in the Fencing of Students

Hamid Aboul Shaheed Hadi, All Mahdi All Almaơhioam, Zaid Sami Yasir, Hayder Nall Habash Alshow

DOr:10.05980976-6506 2019 026774

The Development of Nursing intervention Based on indonesian Nursing intervention Standard on infarction Stroke in Hospita

Hani Riska Alyanti, Nursalam Nursalam, Slamet Riyadl Yumono

DOI. $10505090976-65062019025786$

Relationship between Mental Workload and Fatigue of Motorcycle Rider among East Java Student

LY Hendrafi, S. Martini, K.S. Lestari

DO1-10.595200976.6500.2019.02579

Single Nuclentide Polymorphisms in I-10-1082 AlG Gene and Association with HoMV infection in Abortion

Hiba A Hatem Mayyada F. Oanveesh

DOI:10.5952:0976-5606 2019 02500

Molecular Study of Echinocococus Granulasus in Misan Province. South of iran

Hussain A Mhouse Alsaady, Hussein Ali Nreem A-Quzweent

DOI:10.59620976-6506.201202621:

The Human Arthrogathy infammatory and immune Herd Plots

ibrahim M S Shnawa, Baha H H Alamidie

DOl:10.5958,0976-5506.201902582.8

Congenital Lobar Emphysema-A case Series for 2 Years

ibrahim Shuker Mahmood, Fawzl Salh Shthab, Almad' Mahmood Mohammed

DOI: $1059520976.6509201902503 \times$

The carotid intima-Media Thickness in Workers with High and Low Exposure to Air Pollution

isabella Lalenoh, Muhammad Aminuddin

DO1:10.695e0976-6500. 2012.025e4.1

Using Species-Specific Polymerase Chain Reaction Technique for Detection of Cows. Buffallos, Seens and Goats Milk and cheeses in Basra city Jalal Yaseen Mustafa

DOl:10.59580976.5500.2019.02585.

The Effectiveness of Chelating Property of Chitosan Nanqparticles on Dentin

Jamal A Abu A-timan, Hussain F. Al-tilwaizi, Hayder H. Abed

DOI: $10.59590976-5506201902509$

The collaboration of Health Workers in Provicing integrated Anten atal care at Oepol Health center. in East Nusa Tenggara. Indonesia

Jeffrey Jap, Stefanus Supvivanto, Myoman Antta Damayamt

DOI:10.506e.0978-6506.2012.02627

The Role of Zinc Sulfate in Reducing Levels of TNF $\alpha, \mathbb{L L}-1 \beta$ and $\mathrm{L}-6$ in Multi Basiler Leprosy Patients

Joko Kumbianto, Moh. Sulchan, Kabutraktman, WS Hertanto, HS Suharyo, Praselyowati

The Status of Her2 Expression in a Group of iravi Women with cervical carcinoma

Kawakeb N Abdulla, Basim M. Fhashman, Saba Jassim Aheshimi, Ameer A. Oudah

DOI-10 59520976-5506 2019026999

The immunohistochemical Evaluation of BRCA2 Expression with HPV infection in a Group of iraqi Women with cervical carcinoma

Kawakeb N Abrulla, Basim M Khashman, Saha Jassim Aihechim

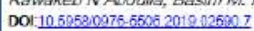

Prognosis Within 24 Hours Using Nursing Early Waming Scoring System (Newss) Method On Left Heart Failure Patients At Mitra Delima Hospital, Malang Luluk Nur Aini, Liliti Suspriati, Titin Andri Whastuth

Lol:10.59580976-5500.2019.02591:

Descriotive Mavoing of Needs among Diabetes Mellitus Patients

Made Kumia Wilasstuti Gin, Adinvana Putra, IMade Kusuma Wijaya, Komang Hendra Setionan, Ni Putu Dewi Sri Wahyuni

DOI:1059520976-6506 201902592:

Evaluation of Malaria Surveillance Based on Atribute in Health Office of East Sumba District

Margaretha Domingga, Atik choind Hidajah

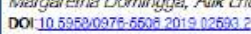

Low Level Laser Therapy on Postoperative Trlsmus and Swelling after Surgical Removal of impacted Lower Third Molar

Marwah Sataa AVi, Sathar Shakir A-Adil

DOI:10.6958.0970.6506 201902604

Role of Betatrophin and irisin on Diabetes Mell tus Type 1 Management (Experimental Study)

Maysaa J. Majeed, Zainabb A. Razak' Al-Sharif, Shifala Jamied ibvahim

DOI: 10.5958 .0978 .55002019 .02596

Correlation between LDL. HDL. LDL HDL Ratio and Preeclamosia incidence at RSUD Pamekasan. indonesia

Mazdalha Rahmawandari Nurhanl. Kusworini, Bambang Rahardie

DOI:1059520978-550\% 2015 026968

Evaluation of the Antbacterial Activity of iraq Garic Derivatives to Escherichia coll

Minen Al-Karajy

DOI:10.59520278-6606.2012.02627.

Effect of Using Zirconla and Metallic Bar Attachment Overdentures on the Supporting Structures of Mandibular Edentulous Ridge Avea (Randomized control Trial) Mohamed Z, Debis, Anw I. Badt, Emad M. Agamy, Gehan F. Mohamed

DOI:10.59580976-5500.2019.02598

The Construction Effectiven ess and Reliability of Mental Health inventory anong Students in Malaysia

Mohammad Aziz Shah Mohamed Avip, Ainiyusnita Abdul Rahim, Umah Devi Muthu Panjasaram, Anne christina Amaladass

DOI-10 $6962.0976-65062019026999$ 
Effect of Immersion Time in $2.5 \%$ Sargassumporycystum Effervescent Granule Denture Cleansing Agent on the Stablitixy

Acryilc Resin Plate Colour, Mohammad Dhama Utama, Harun Achmad, Ihthiahni, Adytha M.L.R. And, F Anissa

DOI: $1059520976-65002019026 \times 0$

Assessment of Vascular Endothelial Growh Factor in the iraqi Patients with Ovarian cancer and its correlation with Angiogenesis Mohamwed Shavent Mahbool, Abdui Hussein Razzaq Ali, Jabbar Fadeel Mahidi Alafloogee

DOI:10.5958:0976-5500.2018.02001:

The Usage of Low Level L aser Therapy Bio Stimulation and Bone Grafting in Accelerating the Healing of chronic intra-Osseous Defects: Vivo Study Muhammed Abouel Seoud, Medhat Kerala, Mouchira Salah El Din, Magdy AV', Adel AboelFartouh

DOI: $10595890976-6506201902602$.

The Effect of Polyamicle Micro-Particles Ad dilion on Some Mechanical Properties of Heat cured Poly Methyl Methacrylate Denture Base Material Mithaq R. Mohammed

DOI:1050520976-6506 2019020203?

Effects of the Use of Self-Directed Video on Knowledge of Malang city's Volunteer communities in conducting cPR Actions Apryani, Retty Ratraweti, lika Setyo Rini

DOl:10.59500976.6606.2012.02024.4

Determination of Reference of concentration (RFC) from Hydragen Sulfide ( $\mathrm{H}_{2} \mathrm{~S}$ ) Exx xosure in the community Based an Weight in industrial Area in Medan indonesia Citra Dew Puspasar, Abdul Rohim Tualeka, Pudy Rahmawat, Syamslar S. Russen, Atjo Wahy, Ahso DOI:1059520976-5506 201902605

Sexual Risk Behaviour of Men Who Have Sex with Men (MSM) in an Urban Society of West Sumatera Province of indonesia Hardlsman Dasman, Firda Firdawatt, Yantri Maputra, Itma Nurka Suifient, Faiz Nur Hanum DOI $10.595009976-550020191902005$

An Exploration of Heath Beliefs Related to Fluid-Restricted in Patients Undergoing Hemodialysis

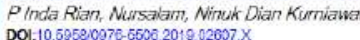

Determination of Dosege Reference (BAD) of Mercury Based on NOAFL and characteristics of Workers in the Area of Unlicensed Godd Mning(PEFi) Maluku Province indanesia Vaninda Eka Pridlanata, Aboul Rohim Tualeka, Bacrudih Lain, Pugff Rahmawati, Syamslar S Russeng, Ajjo Wathy, Ansan

DOI:10 $59589976-5506$ 2019 026391

Using of Blended Leaming in improving collaboration Skill of Nursing Students

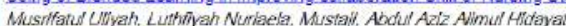

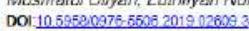

Matemal and Fetal Determinants of Stilloirth among Women Who Attending Maternity Departments of Basra central Hospitals Nadeem R Shiaa, Sallad S. Issa, Bd AL Kareen H Suther

Nadeem R Shiaa, Sajpad S. Is S

Spintual-Based Family care Models to improvement Family Health with Leprosy at Jombang Regency of East Java indonesia

Nasrudin, As Yusuf, Rachmat Hargeno, Tippto Suwandi

DOl:10.59530976.5506.2019.02611.1

Determining Mercury Sate concentration in Shells in the Unlicensed Gold Mining Area of Kayeli Village, Bunu Regenncy, Maluku Province, indonesia

Nesya Eka Ramadhani, Abouil Rahim Tuakeka, Bacrudin Lain, Pudjil Rahmawart, Syamsiar S Russeng, Atjo Wahyu, Ahsan

DOI-10 $59520976-6606201902612$

Synaosin-i Exoression in the Rattus noonegicus Pup's Brain from Rat's Maternal Death Mode

Nur Maziyah Hurin in, Hermanto In' Joewono, Wolfat

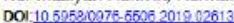

Toluene Safe concentration for Toll Gate Keepers at Kebon Jeruk, Jakarta indonesia

Nur Vita Widianingrum, Abolu Rohimn Tualeka, Pudji Rahmrawati, Syamsiar S Russeng, Ajjo Wahyu

DOI:10.5958.0976.5506.2019.026147

The Effect of Fermentation of Qyster Mushrooms on Millet Grain of Healthy Japanese Quail Diets on Some Productive and Physidagical Traits

Ola H. Abdul Ameer, Yasser J Jameel, Mahdi A. All

DOI:10.59580976-6506 201902615

Effect of Acylation. Esterification and Deamidation on Functional Properties of camel Milk caseins

Qausar Hamed ALKaisy, Jasim M. S. Al-Saad'

DOI:1059520076-6509 201902616

Implementation Program of child Under 5 Years' Growth and Develooment Problems in Bangkalan, Madura

Qurniva Andayani, Toetik Koesbantiati, Windhe Pumorno

DO1:10.59620976-6500 2012.026172

Effect of Exercises Using Devices to Develop Some of the Motor Qualities and Offensive Basketball Skills

Rasha Talli Dheyab, Omar Saad A/med

DOL:10.69580976-6506 201902619

Implementation of 5 peech Therapy and Social Stories increasing Social interaction in children with Autism

Retro Twstlandayant, Krowioh Umah, Dede Nasnullath

DOI:1059520976-5506 201902619:

Determination of Safe Sulfur Dioxide $\left(\mathrm{SO}_{2}\right)$ concentration among Street Vendors of Ampera Bus Station, Palembang, indonesia

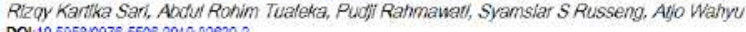

DOI:10.5960.0976.6506.2018.02020.

The Influence of Training Handover hased SBAR communication for improving Patients Safety

Roymond H, Simamora, Achmad Fathi

DOI:-10 59580976-5506 201902755 4

Effects of Nigella Saliva Oil on Biochemical Parameters of White Male Rats Exposed to Diazinon

Rusui M. Alhilo, Hussain I. Kadhim, Mahammed T. Abbas

DO1 $10.59520976-56002019026214$

Role of Serum Activin A and Granulocyce Macrophage-colony Stimulating Factor in the Prediction of Pregnancy Qutcome in PCOS and Non-PCOS Women Following ICS Saad'S. Al-Dujally, Nagham T. Shukey
DOl-10.60580976.6500.2019.02622.6

Influence of Percention about their Partners and Marital Status an Prevention of HiV ADS Transmission among Papuan Women in Sarong aity Soriana Pangaribuan, Chatarina Umbul Wahyuni, Hari Basukt, Avi Probandan

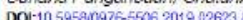

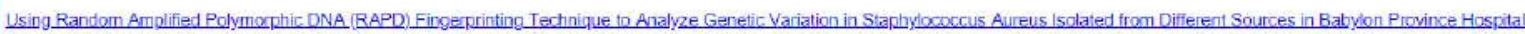
Shaima R. Bancon, Zahraa Kamli Kadhim, Zahid'S. Aziz, Zahraa Isam Jameel, Rugava MS SW Eadh

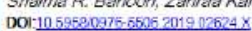

Effect of Using Distal Extension Bar on the Posterior Ridge Avea in implant Supported Mandibular Overclentures

Shenif M. Akde' Hamid, Ahmed'G. Hamzaw, Emad M. Agamy, Gehan F. Mohamed'

DOH-10.5950.0976-6606 201902625.

Salivary and Seral Sex Hormones in Kelation with Feriodontal Froblems

Sulata Khair Al-Deen Banoos'

DOl:10.5959.0976.5506. 2019:02626

Effectiveness of Soursop Leat Extracts on Decreasing Blood Sugar for Type-2 Diabetes Mellitus Patients

Ta'adl, Mard' Hantono, Sunarto, Choiroed Anwar

DOI-106059:0978-6500 201902627:

Effectiveness of Mini Long Protocol in Patients with Prevlous IVF Fallure Due to Poor Resoonse

Thuraya Hussamuldeen Abolull, Sumaya Taher Sayhood, Alaa Mohamumad AVKhawaz

DOI:10.5958.0976-65009201902023 
Comparative Study for Preemptive Administration of intravenous infusion of Nefopam Versus Paracetamol in Providing Postoperative Analgesia for Patients Undergoing Anterior and Posterior Vaginal Wall Repairs Under Spinal Anesthesia

Yasir Fadil Muhammad Ali Alkhazrail Sahar Swadi Raheem, Qatal Al-Nada Adran Abood

DO1:10.5959.0976-5506 201902630

Imparct of Thyroid Dysturction on control of Diabeles Mellitie

Zahraa Aboulaall A-Mudhafar, israa Nhad Ahmed, Mohammed Sami Turk, Safaa All Khudhali

DOI:10 5958,0976-5506 201902631 ?

Study the Effect of Cladosporium Spp, on Some Internal Organs of Experimental Animals

Zainab R. Zghair

DOI:-1059820976-6506 201902632

The Effect of Addition of White Portland Cement on the Physical Properties of MTA Fillapex

Rehab Ali Farag, Maged M. Negm, Magdy M. Ali, Lamia 1, Almed

DOl: $10.59580976-5500.2019 .02633$

Effectiveness of Generative Leaming Strategy for Those with cognitive Style(Riskicaution) in the oggnitive Achievement and Motor compatibility and Leaming the Recaption Skill (Pass) of The Student in Volleyball

Hatem Flayy Hafedh, Amer Husse'n Ali, Zaman Tork Hashim

DOI:-10 5952:0978-6509 201902024

Risk Factors of Rotavirus infection among children Hosoital sed with Acute Diarrhoea in Sabah. Malaysia Bomeo

Abraham chin Zetong, Mohammad Saffree Jeffree, Syed Shanizman Syed Aboul Rahim, Firdaus Hayab, Khamisah Awang Lukman, Mohd Yusofibrahim, Kamrudin Ahmed

DOI:10.5958:0976-5500.2012.02635.4

Factors Infuencing Contraceptive Use among Reproductive-Äge Women in East Java, indonesiat

Aff Kumiawan, Diyah Herowat, Kuntoro, Avief Wibowo

DOI: $106958,0976-6506201902636$.

Processes of change for Weight control Behavior among collegians

Ahmed Adll All Basha, Arkan Bahiol Naj"

DOI:105052:0976-6506 201902637.

Estimation of the Width of Un-Erupted canines and Premolars in Basrah Population: A cross Sectional Study. Ali S. Thedan, Hasanen A. Ainamel, Rafid M. Albadr

DOl:10.59520078-6506.2018.02028.x

An Analy ysis of Factors Associated with the Relapse History of clients with Schizoghrenia at an Outpatient Polyclinic

Alifiatul Oza Hamanu, Ah. Yusuf, KRlzhd Fityasarf Patra

DOI:1059520976-6506 2019 02839

A Dilemma of Morality in Euthanasia Problen

Aminuddith Prahatama Putra, Huidant, Bayu hndra Sukmana, Favzlah, Hann Achmad

DOI-105950.0978-5600 201902840.8

Effect of ChannaSmiata Exract on the Expression of Tumor Necrosis Factor-a (TNF-ci) in Rat Experience Periodonitis

Amal Mardiana Adam, Hasanuddin Thath, Harun Achmad

DOl-10.59520976.6506. 2019.02641:

Effect of Moringa Leaf Extract (Maringa O'delfera) on increasing the Number of Osteoblas as a Marker of Bone Remodelling

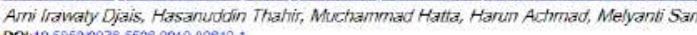

DOI: 10.5958 .0978 .5500 .2019 .02642

Oral Health condition among Kindergarten children in Relation to Salivary soluble Cluster of Differentiation 14 and Tool Like Receptor 2 (comparative study)

Aseel Taha fhaudyer, Ahtam Taho Mahammed, Barool Hessan At-Ghumb

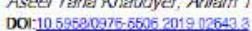

Determination of Serum and Seminal Gamma Glutamyd transferase (GGT) on Sperm Parameter in infertle Patients

Asmehan Adnan At-LNageeb, Muhammed Baqir M-R. Fakhnilitin

DOI-10.09520976-6606 2019020645

Utilization of Lactobacillus Acidophilus FNCc-0051 Microencansulation: Potential Benefit of Giving Combination of Sodium Alginate and Gelatin to Autributes and Role of Probiotic Agains Staphylococtus Aureus

Arumentin Diana, Tutiek Purwanti, isnaen

DOI:10 59580976-5656 2019026457

The correlation of Sleep Quality Factors in Overweight Adolescents in a Developing country

Nur Faizah, Flida Ulifana, Setho Hadisuydtrman

DOI-10.55580976-5500.2018.02846.9

Carbon Emission Disclosure in Manufacturing companies in Indonesia

Bangun Tri Saputro, Basuk

DOl-10.595809765506 201902647

The Effectivity of Brain Gym and Memory Games Theraby for imprewing cogritive Function in Fiderly Pegole with Dementia

Maulana Anif Murtacho, Elloda Uifiana, Setho Hadj Suratmana

DOI: 10 59520976-6506 201902649 2

Effects of intensity of Reading Short Stories Activites and Retelling the Story on Elderly cognitive impairment

Devi Avu Kumalasari, Hanik Endang Nihayatt, Elida Uifiana, Rista Fauziningtivas

DOI:10.59520078.6506.2012.02640.

The Influence of Dhakonan Games to Impede Dementia in Elders

Mita Nur Lathifah, Joni Hasyanto, Rista Fauziningtyas

DOI: 10.59580976 .6500 .2019 .02050

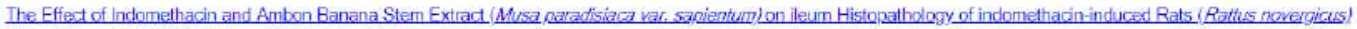
Dian Afikasari, Kaclek Rachmawati, Romziah Sidjik

DOI:1059580976-5506 2019 0275:

Atrenuation of Ekmenia tenella with immersion Various concentration of Fomaldehyde in inducing Protective immunity after challenge Test by Featuring Macroscopic and Microscopic caecum Rizkl Rohmah Armianl, Muchammad Yunus, chaind' Anwar Nidom

DOI:10.50520976-6506.2019.02652.

The Potential of immune Response improvement through Brucella aboartus Outer Membrane Protein and Whole Brvedla abontus S19 Vaccinations on White Pulp Diameter of Lepus nilgricolilis Mushanmad Ardeansyah, Chairul Arwar, fmam Mustoda

DOI:10.5958:0978-5500.2012.02653.

The Effect of Addlog Maringa Leave (Marioga delfera) 10 Male Broiler Fee

Mien Quirati Aynni Muis, Kadek Rachmawati, Monammad Anam Al Anit

DOI:10 59580976-5506 201902654

The Effect of Vitamin on Wistar Rats' Testicles Exposed to Lethal insecticide

Gahrlelia Ayu Pitaboka, Kusnoto, thomas Vatentinus Whilyatno

DOI-10.5952:0976-6506 2019.02655X

The Potency of Formalin in Arenuation of Pathogenicity in Eimerta Tenella at the caecum of Broiler chicken

Enik Setyowathi, Muchammad Yunus, Dadik Rathardjo

DOI: $10.59580976-6500201902650$.

Fasciolosis Prevalence on Several cattle Breeds

Kurnia Winda Pratiwi, Setiawan Koesdanto, Nenny Haryjani

DO1:10.59580976-5506 2019:02657.

BPJS Kesehatan Patients Satisfaction on Pharmaceutical Services in Community Healih Center (PUSKESMAS)-South Surabaya Area

Assyifa limi Aulfya, I Nyoman Wijaya, Cotur Dlan Setiawan, Gesnita Nugraheni

DOl:10.59520976-6596 20190265e

The Effect of Lower Extremity Massage with Lavender Essential Oll on Decreasing Blood Pressure in Elderly with Hypertension in UPTD Griya Werdha Surabaya

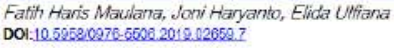


The Effectiveness of Afternoon Sunbath in Improviry Eldedy Sleep Quality

Zaenal Abidin, Harmayetry, Denl Yasmara

DOH:-10 59580976-5506 2019026515

Family Burden and cooing in Family caregivers of Patients with Schizophrenia

Winda Kusumawardani, Ah, Yusuf, Lailatum Ni'mah

Antibacterlal Activitles of Exiract in Butanol-Merhanol (1: 1) Filtrat of the Fermentation Results of Sireptomyces sp. B10 Against Mveabacterium tubercuinsis H37Rv: An Experimental Study. Septa Devi Adetya Putri, isnaeni, M. Faris Adrianto

DOL-10.5058,0978-5508 201902053

The correlation between Goat Maintenance Management to the incidence of Gastrointestinal Parasite infections

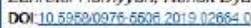

Histopathology of Esophagus and crop of Pigen (Columbla livia) infected by Thiohomonas gallinare

Aprifia Eva Widiawati, Muchamad Yunus, Thomas V Widjiatio

DO1:10.59580976-5506:2019:02005.2

The Fffectiveness of Back Fxercise for the Reduction of L ow Back Pain Prevalence on the Emergency Room Nurses

Dinda Nur Faji hicayati Bunga, Hanmayetry, Candra Panf Asmoro

DOI:10 59580976-5506 2019 02656

The Effect of Breeding Management on the Prevalence and Trematode infection Degree in calves

Haris Setlawan, Kusnoto, Messud Harladt

DOI-1059520976-6506 201902657:

The Effectiveness of Cmodon dactyon Leaf Extract as Hepatoprotector in Liver Damage of Hyperglycemic Mus muscutus

Ade Mahendra Putra, Retno Sri Wahiuni, Rakhaju Emawati

DOI:10.5958:0976-5506.2019.02608

The Relationship between the Forms of Social interactions and the Life Quality of the Eldert:

Muthmainnah, Elida Ulfiana, Setho Hadisuyamana

DOI:10 59580976-5506 201902659

Educational Game Methorls of Attaching images to Slide calendar towards Sctool-Age children's Knowedge and Attitudes on choosing Healtib Snacks Adzan Fachrumozi, Tyas Kusumaningrum, Praba Diyan Rachmawatt

DOR:10 59580978-6506 2019:02670

The correlation between Dementia Severity and caregiver Burden Level in community

Eryin Sulistyant, doni Haryanto, Maktroudl:

DOI:10.59580970.5500 2019.02671:

An Exploratory Study in the indonesian Archipelago: Are There Influenza B Virus (B-Victorla Sub-Type) in the Bat's Respiratory Organs? Muhammad Ahas Widanu Rahman, Chairul Anwar Nidom, Setya Budhi

DOI:10.5958.0976-5506.2019.02672

Factors Inffuencing Publishing Scientific Papers among Lraqi Medical Acadernic.

Yossra K Hanoon, Riyach KLatia

DOI: $10.59530976-5606201902673$

Effect of Eating Even or Odd Number of Dates on Blood Glucose Leve

Yossra K. Al-Robalaay, Maha A. Al-Nueimt, Tawteed F. R. AL-Auqbi

DOI-10.09520076-6509 201902874.

Management of Slum Sertings Through the Private dity Program (Kolaku) Towards a city of Heaith, Makassar indonesia Haslinali Ahmad, indar, Sulvi Pafluturi, Suriah, Ahrnad Yant

DO1:10.59580976-5506.201902675.

Prosthodantics Rehabilitation of a Surgically Repraired Cleft Palate Patient with Tooth Surpurted Telescopic. Over Denture Prosthesis: Case Study.

Pryaanka Debta, Anurag Danl, Fakir Mohan Debta, Santosh Kumar Swaih, Somalee Mahapatra

DO: 1059580976-5506 201902676

Achondroplasia in an Eleven-Year-Od Male Child

Satya Ranfan M/sm

DOI:1059520976-5506 201902677

An Introduction to Preventive Orthodontios

Snigdina Pattanalk, Swati Pathat

Minimal Invasive Surgical Anproach for Treatment of Excessive Gingival Displav: A Case Recont

Gatha Mohanty, Alhaya Chandra Das, Anurag Satpathy, Saurav Panda, Rinkee Mohan

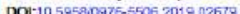

Unusual Presentation of Dentigerous Cysts Arising fiom Complex and Compound Odontomas

Shubhangi Pareek, Swagatika Panda. Subrat Padhian, Sreecreeti Champatyray, Neeta Mohanty

DOI-10 $1095909976-5506.2019027528$

Surgical Clinical Crown Lenothening: A Prerequisite for Crowm Placement in Fractured Teeth

Abhayla Chandra Das, Saurav Panda, Manci Kumar, Saumya Kanta Mohanty

DOI:10.59580976-5506.2012.02680

Immediate Placement of Implants in Fresh Maxillary Anterior Toath Region: 18 Manths Follow Un: A Case Report

Monika Samal, Sreeprada Dash, Gunjan Srivastava, Sitansu Sekhar Das, Bodhisatta Mukherjee

DOI:10 59590976-5506 2019026310

Recurrent Respiratory Parillomatosis: A Comprehensive Reviev

Santosh Kumar Swain, Privanka Debta, Smrutipragnya Samal, Jatinaro Nath Mohanty, Fokir Mohan Debta, Anurag Dan

DOt:1059520976-6506 201902692 2

Lateraly Pedicled Flap and Connective Tissue Graft for Management of Orthodontically Inflicted Gingival Recession-A Case Report

Saurav Panda, Sital Panda, Anurag Satouthy, Abhaya Chandra Das

DOI-10.59520078.6500 20100003

Life Threatening Involvement of Bilateral Total Maxilla by a Large Radicular Cyst: A Rare Case Repont

Harsh Mohan Pathak Sabhan Mishra, Neota Mohanty Sanchar Sinha Roy Satchiclananda Meher

DOI:10.5958.0976-5506.2019.02684.

Meclical Tourism Prosperts and Challenges

Shaktl Rath, Naushaba Akhtar, Sangram Panda

DOI:10 59580976-5506 201902635:

Multiple Major Aohthous Ulcers: An Uncommon Presentation

Satya Raryian Misra

DOI:10.59520976-6000 2010.02602.X

Antiplacue Efficacy of a Dentifice Containing Low Concentration of Chborhexidine: A Randomized Controlled Clinical Tria

Adrita Purkayas tha, Rinkee Mohanty, Anurag Satoathy, Rashrnita Nayak, Rajdeev Beura, Uthalikla Das

DOI:-10.5958:0976-6500 2019.02687

Temporomanthoular Joint Disorders; Etichgical Factors, Diagnosis and Treatment

K.L. Sushmita

DOI:10 59580976-5506 2019026893

Potentially Malignant Oral Lesions: A Clinial Perspective

Suryasnata Nayak, Shashirekha Govind, Amit Jena

DOI-1059620976-6506 2019 02699: 
Prosthetic Rehabilitation of Ocular Defect A Case Regort

M. Krishina, Abhijita Mohiapatra, Gopal Krishina Choudhury

DOI:10.5958:0976-5500.2019.02000.

Accelerated Orthodontics: A Boosito Orthodontic Treatment Ananya Panda

DOl:10 59580976-5506 2019026913

Diagnostic Features of Oral Ulcers: An Overviev

Surrantita Jena, Rupsa Das

DOI:10 59850976-5606 201902692.

Conventional Over Denture-A Successful Clinical Protocal to Treat Edentulous State: A Case Report

Sangram Panda, Gopal Krishrna Choudhury, Surnita Mishra

DOl-10.59580976-5500.2012.02028.7

Modified Coronally Advanced Flap Procedure Using Onthodontic Buttons: A Case Report

Saurav Panda, Sital Panda, Abhaya Chandra Das, Rinkee Mohanty
DO1:10.5959.0976-5506 2019 02694.9

Pindbarg Tumor: A Report of Two Cases

Basanto Kumar Chourhury, Shayari Nigogl, Pinall Das

DOi:10 59520976-5506 201902695

Hypohidrotic Ectodermal Dysplasia in a Young Male Patient

Satya Raryian Misra

DOH:10.5050070 05002019020982

Management of Mandbular Resorbed Ridges by Combining Two Impression Techniques: A Literature Review and Case Repont

Sreeprada Dash, Gunjan Srivastava, Gopa/ Krishna Choudhury, Debashish Sahoo, Monika Sam

DOI:10.59580976-5506.2019.02697.

Evalutian of the Begg's Arodiance

Singoha Pattanalk

DOI:10 59580976-5506 201902699

Glyootic Acid Peel for Gincival De-Pigmentation: A Case Repor

Rashmita Nayak, Sheetal Acharya, Anurag Satoathy, Rohina Sharnim, Pratiti Datta, Bikash Kar

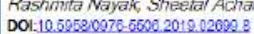

Laser Assisted Frenotomy with Coronally Positioned Flap for The Treament of I solated Mandibular Ginglval Recession

Abhaya Chandra Das, Saurav Panda, Sauniya Karta Mohanty, Nitai Debnath

DOI:10.59580976-5506.2019.02700.1

Endascopic Treatment of Sinonasal Ossiffing Fibroma: A Case Recon

Santosh Kumar Swain, Pryyanka Debta, Smrutioragnya Samal, Jatindra Nath Mohanty, Fakir Mohan Debta, Anurag Dand

DOI:10 $59580976-55062019027013$

Management of Medical Emergencies in Dental Office

Ananya Oujwoswini

DOI:10.59520076.-5509.2019.02700

A Rare Case Report of Recurrent Basal Cell Adenoma Involving Minor Salivary Gland of Hard Palate

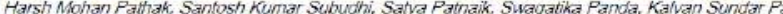

DOI:10.5958:0978.5502 2019.02703

The Relationship between Nutrition and Oral Health: A Review

Sourav Chandra Budyasagar Bal, Sukhvinder Singh Oberoi, Raoha Prasanna Daiai, Ameet Obero

DOI:10 59580976-5506 201902704

Reproductive Health for Adolescents with Intellectual Disabilities: The Irodementation of a Psychoeducation Module for Special Fducation Teachers in Bandung City, Indonesia Sela Fasya, Evi Martha, Hadl Pratomo, Frieda Mangunsong

DOI:10.59530976-6506 201902706

Cost Effectiveness of Interventions Using the TB Dors Strategy in Public Heathcare and Private Hospitals in Depok, West Java, Indonesia Fikrotul Ulya, Hasbullah Thabrany, Mardiati Naditib, Pumawan hunadi

DOI:10.5958:0978-5500.2018.02708.2

Determinants of Nurse Quality Service in Jakarta Private Hosolta

Bernadetha Nadeak, Sasmok

DO1:10.59580976-5506.2019.02707

Analysis of Clinical Pathway Implementation on Pneumonia Case in PMI Bogor Hospital

Musilyath Syahrawani Elsa, Atik Nurwahpun

DOI:1059890976-6506 201902709

Effects of Servant Leadership and Training Programs on Servant motivation of Hosoltal Medical Personne

Bernadetha Nadeak, Sasmoho

DO1:10.595a.0976.5506.2019:02709.

The Role of Environmental Leadershio and Personalifyen VBN Model

I Made Putrawan, L/sa Dwi Ningrtyas

DOI:10.59590976-5606201902710

Environment and Commitment. Locus of Control and Intention to Act

Erlan Fatria, i Made Putrawan, Guspri Devi Antanti

DOI-1059520976-6600 201902711

The Psychometrics Evaluation of Administrative Staff's Jab Satisfaction

Vema Aisya Rałma, Lokjnan Mohd Tahis, Narina A. Samah, Sanitah Mohd Yusof, Rohaya Talib, Noor Azean Atan

DOI:10.59590976-5506.201902712

Reliability of Sullivan Emotional Intelligence Scale for Children in Malaysian Context Using Rasch Measurement Mode

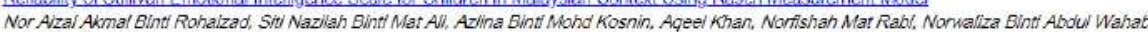

DOI:10 59580976-5506 2019 202713

Onine Trust: Examining ldentity on Health Related Tourism Websites in Scutheast Asia

Mohammad Al/ Mos/ehifar, Noar Alreen thrahim, C. Sandaman

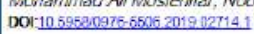

Copinc Strategles and Challenges among Intemational Marrled Postgraduate Students in Universill Teknoloci Malavsia

Naries Ratmani Movahed, Mahani Mokhtar, Zainudin Hiassan

Naljes Ratmatri Movahed, Mal

Improving Spatial Visualization Skills in Fducational Settinge

Marlissa Omar, Dayana Farzeeha All, Johari Surit, Mahani Mokntar, Nund Farhana Jumaat Norazrena Abu Samah, Zakiah Mohamad Ashari

DOO:1059580976-5506 2019027165

Enhancing Iraining for Multicultural Counselirg Efficiency Acosording to the School Counselors Perspertive Toward Clients Psychological Health

Kamaru' Md Shoh, Ageel Khan, Rozita Jayus

Do: 1059680976-6506 2019027177

Does Psychological Empowerment Mediates the Relationship berween Leader-Member Exchange and Organisational Citizenship Behaviour among Nurses? Jurialdah Yusof, Sitt Aisyath Panatik, Azizath Rajab, Norakmar Nordin

DOI:10.59580978-5500.2019.02718

Social Support. Ootimism. Parental Self-efflcacy and Welloeing in Mothers of Children with Autism Spectrum Disorder

Farhan Sawar, Siti Aisyah Panatik, Azizah Rajab, Norakmar Nordin

DOI:10.59580976-5506. 2019.02719.

Employee Peffomance of Private Hos pital Non-Medical Services

Bernadetho Nadeak, Sasmoko

DOI:-10 69520976-6506 201902720 
Perceived EHfects of KOACl.COM Heath Campaign Targeting Mother-Child with HIVIAIDS in Cote d'Ivoire Hasmah Zanuddhl Ousmane Koff Abdoulaye

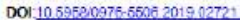

Do Demographics Matter? A Study on Administrative Staff's Satisfaction Level Towards their High Education Institutions Lokman Mohd Tahir, Narina A Samah, Sanitah Mohd Yusof, Mohd Fadzli Ali, Noor Azean Atan, M. Al-Muzammil Yassin DOI:10.5958.0976.5506.2019.02722.

Benefils of Breast Mik for Health Care Analysis from the Istamic Perspective

Nomadiah Daud, Hamizah ismall, Sit Roshaidal Mohd Anffin, Rahimah Embong. Nauhhrah Nordin, Ado Abou Bichl

DOI:10 59580976-5506 201902723

The Importance of Menu Variety Experience for Public Hea th Sustainability at Higher Education Institution

Sarimah ismall, Namah Kadl, Avif Kamisan Pusiran, Itha Saftit Zen, Ageel Khan

DOI-10 5958.0976 .6509201902724

Spectrofluorimetric Method for the Determination of Rhodamine B in Sysup

Asmiventi Djaliassin Djall, Bondan Bagus Wijaksono, Pri iswati Utami

DO1:10.59580976-5500 2019 02725.8

Heary Change of Accertor Contracention Body in Depo Medroxy Progesterone Acetat (DMPA

Susanti, Annisa Nuru/ Chusna

Di:10 $59500976-506201902750$

The Overview of Malaysia HIV Counselling Structure

Nurain Balqls Haledih, Noor Aireen Itrathim, Azzzah Rajab, Yasmin Hanafi Zaid

DOI-1059590976-5506201902726.

A Systematic Review of Learning Application for Students with Dyslexia

Kee Jiar Yeo, Wai Wai Lim

DOI:10.59580976-5500.2012.02727

Diagnostic Qutcomes of Pancyocenia after Bone Marow Examination in Lady Reading Hospilal, Peshawar

Huma Rizz, Munawar Ali Shah, Tail Aif Whattak

DOI:1059580976-5506 201902728

Perceived Causes of Infertility: Accounts of Infertile Individuals in Kusra South, Nigeria

S/welumor Olunakeml, Sharifiah Suraya Syed Jamahdilin, KBabarunde Seun

DOI:10 59580976-5506 2019 02729

The Correlation Between Education and Occupation with the ANC (Antenatal Care) Visit at Nagaswidak Heath Care Center Palembang Resy Asmakifa, Asmarani Makm

Sanctioning System in Regulatory Enforcement of Medicine in Malaysia

Sanctioning System in Regulatory Enforcemen

Dol:10.59590976-5056.2019.02731.1

Eating Disonder, Body Fat Percentage, and Physical Activity Among Sarawak Female Naticnal Athletes

Patricla Pava PIthl, Wan Jullana Emeilh Wahed

DOI:1059520976-5506 2019 027323

Improvement of Anide Brachial Index (ABI) Using Foot Bath Therapy at a Temperature af $40^{\circ} \mathrm{C}$ in Patients with Diabetes Mellitus

Nur /smaint, Bektit Nurpri Setyani

The Theoretical Model of the Influence of Extraversion Personality and Ootimism on Subjective Well-Being by Coping as a Mediator

Nur'aen, Asmadi Alsa, Anizar Rahayu

DO1:10.59580976-5506 2019:02734

Social Skills for Suident Social Arniety Disorder (SAD) in Flementary School

S. Siryanto, Tri Nalfmah, Yutha Febrianta, indri Mumiawaty

DOI:10 5958,0976-5506 2019 02735 9

Therapeutic Intervention of Respiratery Tract Cases in Children

Um/ Solikhah, Sitr Nuglannah, Supriyad

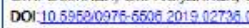

Mortality Rate and Gonotropic Cycle Serotipe Denv-2 Transovarial Transmission through Intratoracal

isna Hiknawati, Hendro Wahjono, Mortini, Soeharyo Hadisaputro, Edf Damana, Kosdjamiatun Retna Mustika Djati, Sugeng Jumono Mardihusodo

DO: $10.5958,0976.5500201902737$

Validaring the Measurement Model of Prohlem Solving Strategles and Marital Communication Styles among Secondary School Teachers in Nigeria Fasasi Lukman, Ageel Khan, Adibah Aboul Latiti, Ado Abdu Bichi

DOI:1059580976-5506 201902739

Validation of Anxiefy, Life Satisfaction and Social Media Addiction Scales using Rasch Measurement Approach

Ramatt Muthammad Maiwada, Apeel Khan, Adibah Abdi' Latif

DOI-105958.0976-6506 201902739

Psychological Hapoiness and Meaning of Life among Students of King Khalid University Saudl Arabia

Ziyad Al-Tanawneh, Nashast Baioumy, Rahimahi Embong, Rosjan Ab Rahman, Ado Abdu Bichi

DOl:10.59580976-5500 2018.02740 .2

The Influence of Larvitraps Modification as the Monitoring of Aedes Aegxpil Larvae Existence at the Area of Rajabasa Indah Heaith Center Technical implementation Unit Ayu Rizky, Khoidar Amirus, Agung Aji Perdana

DOl:10 59580976-5506 201902741.

A New Risk Calculation Method for Tuberculosis (IB) based on Derision Tree and Avificial Neural Network

Monisha Ghosh Srabantl, Eko Supnyanto, Muhammad Nabll Mohd Warid

DOI: $10.6958 .0976-6506201902742$

Safery Critical Element Methodology in an Oil and Gas Company

Fernando WH Deddy, Zuthithi Ojunaidi, Mila Tejamaya

DO1:10.59580976-5506.2018.02743.

Linkage Model of Brand Eguity and Word of Mouth Toward Purchase Intention in Surgery Speciality Hospital Ropanasuri Padang, Indonesia Numaines, Adhyka, Ratni Prima Lita, Rima Semiarty

DOl:10.5958,0976-5506 201902744.X

Effect of Repeltive Transcranial Magnetic Stimulation on Cortical and Motor Outcomes Post Stroke: A Randomized Controlled Trial

Mohammed S. El-Tamawy, Moshera H. Darwish, Saly H. Elkholy, Engy Badreldin S. Moustafa

DOI:10 59580976-6506 201902745.

Correlation Studv of Functional Performance between Diabetic and Non-Diabetic Patients with Knee Osteoarthritis Abla M Harned, Mahamed H. Aboeleinen, Hala A Abdelgawad, Shimaa N. Aboelazm
DOl:10.5950.0976-6500 201202746.3

Implementation of Enhanced Recovery after Surgerv for Endometrial Carcinoma: A Non-Randomized Controlled Trlal

Ahmad Sameer Sanad, Essam El-Gindi, Rehan R El-Khateeb, Ahmed M Abdl-Ghany, AnnNady Abdelrazik, Ahmed Bakt Mousa, AhmedShoukry hafiz DOl:10.59580976.5500 2018:02747

Can Plasma Cystatin C Predict Clinical Outomes in Hospitalized Patients with Acute Decompensated Heart Failure?

Amir Mostafa, Karim Sald, Walld Ammar, Anmed Elsayed Eltawil Magdy Abded Hasnit

DOI:10 59580976-5506 2019027497

Effect of Dexamethasone on Marbofioxacin Residues in Rabbit Tissues Using HPLC

Gamal A. Shams, Hosny A. Whahim, Ashraf S. Darwish, Hend A Mahmoud

DOI:10.526800978-6506.2019.02749.8 


\title{
Attenuation of Eimeria tenella with Immersion Various Concentration of Formaldehyde in Inducing Protective Immunity after Challenge Test by Featuring Macroscopic and Microscopic Caecum
}

\author{
Rizki Rohmah Armiani', Muchammad Yunus ${ }^{1}$, Chairul Anwar Nidom \\ ${ }^{l}$ Faculty of Veterinary Medicine, Universitas Airlangga, Mulyorejo Street, Surabaya, Indonesia
}

\begin{abstract}
Background: Eimeria tenella parasite is one of the most pathogenic coccidia that can infect chickens. The strategy for prevention and control of coccidiosis is done by administering anticoxidia drugs and live oocyst vaccines. However, anticoxidia can cause resistance to coccidiosis. So it is necessary to make vaccines (attenuation) using formalin or formaldehyde.
\end{abstract}

\begin{abstract}
Aim: The purpose of this study was to determine whether the attenuation of the pathogenicity E. tenella with immersion various concentrations of formaldehyde can induce protective immunity and the concentration of formaldehyde that is most effective in inducing protective immunity for attenuation of E. tenella in featuring cecal macroscopic and microscopic (lesion score).
\end{abstract}

Method: Twenty-five chickens at three weeks old were divided randomly into five groups. Challenge test did after the first infection. The first infection was inoculated tenella by divided the first group (P0) is chicken group was inoculated with $0 \%$ formaldehyde soaked E. tenella at $1 \times 104$ doses as control, the 2nd, 3rd and 4th groups (P1; P2, P3 and P4) were inoculated $0.15 \%, 0.3 \%, 0.6 \%$ and $1.2 \%$ of formaldehyde soaked $E$. tenella at the same doses, respectively. On challenge test performed two weeks after the first infection by inoculated $15 \times 103$ infective oocysts of E. tenella.

Result: The results showed that the attenuation of E. tenella with immersion various concentrations of formaldehyde can induce protective immunity by featuring cecal macroscopic and microscopic (lesion score).

Conclusion: The most effective concentration of formaldehyde in inducing protective immunity of the attenuation pathogenicity E. tenella was $1.2 \%$.

Keywords: attenuation, E. tenella, formaldehyde, protective immunity

\section{Introduction}

Poultry coccidiosis is an intestinal disease caused by Genus Eimeria parasitic protozoa ${ }^{1}$. Eimeria multiplies in the digestive tract and causes damage to the intestinal mucous tissue ${ }^{2}$. Eimeria causes damage to the intestine

\section{Correspondence Author:}

Muchammad Yunus

Faculty of Veterinary Medicine, Universitas Airlangga, Mulyorejo Street, Surabaya, Indonesia, 60115

Email: muchammadyunusfkhunair@yahoo.com thereby reducing the efficiency of feed use, body weight, decreased endurance, and decreased egg production ${ }^{3}$. Coccidiosis in chickens is located in two places, namely the caecal (cecal coccidiosis) caused by Eimeria tenella ${ }^{4}$. Eimeria tenella parasites develop in cecum cells, which are two dead end sacs near the back end of the small intestine. Eimeria tenella parasite is one of the most pathogenic coccidia to infect chickens. Acute infections often occur in young chickens. Infection can be characterized by blood in the stool and with high morbidity and mortality ${ }^{5}$. In addition, the immune response for Eimeria involves many aspects of both the cellular and humoral immune mechanisms ${ }^{6,7}$. 
So far, strategies to prevent and control coccidiosis are carried out by anticoxidia and live oocyst vaccine ${ }^{8,9}$. However, anticoxidia can cause resistance to coccidiosis ${ }^{1}$. The development of increasing anticoxidia drug resistance has stimulated the search for biological control methods by vaccination. Some vaccines have been tried in the form of whole attenuated oocysts ${ }^{10,11}$. One potential explored vaccine material is a live vaccine from oocysts that can be developed, produced and applied in the field ${ }^{12}$. The development of live vaccines using low virulence lines from Eimeria oocysts can be used as an alternative for more efficient and effective protection compared to other coccidiosis vaccines, such as vaccines containing switched off microorganisms and subunit vaccines. Vaccine making can be done by activating or weakening the organism (attenuation) ${ }^{13}$. A simple way of attenuation can expose the organism to active chemicals to the limits of sublethal concentrations such as the use of formaldehyde or formalin.

Giving vaccines can stimulate the body to form antibodies to the Eimeria antigen so that the chicken is able to deal with new infections (challenge tests). The use of separated Eimeria types in vaccines makes it easy for users to apply vaccines according to the prevention of the desired disease. Based on this, the purpose of this study was to determine whether the attenuation of the pathogenicity E. tenella with immersion various concentrations of formaldehyde can induce protective immunity and the concentration of formaldehyde that is most effective in inducing protective immunity for attenuation of $E$. tenella in featuring cecal macroscopic and microscopic (lesion score).

\section{Materials and Method}

This research was conducted at the Laboratory of Parasitology, Faculty of Veterinary Medicine, Universitas Airlangga, Surabaya, Indonesia, from August to September 2016. The experimental animals used in this study were 25 broiler chickens strain CP 707 produced by Charoen Pokphand. The chickens were two weeks old and breed in a battery cage in Besah Village, Kasiman District, Bojonegoro Regency, Indonesia. Eimeria tenella inoculation was performed on 3 weeks old chickens after being adapted for 1 week by ad libitum feeding and drinking. Feed which given, it does not contain koksidiostat.
Calculation of Dosage: Calculation of dosages of E. tenella oocysts was carried out using micro pipets measuring 1-10 $\mu \mathrm{l}$ and white chips. The suspension of $E$. tenella oocysts was diluted using distilled water then the diluted liquid was vortexed so that both materials are homogeneous. The oocyst calculation was carried out by dripping $1 \mathrm{~mL}$ oocyst into a glass object with 5 replications and then calculating the number of oocysts found in all replications with a 100x ratio and looking for an average. From the results of calculations in the average can be 15,000 oocysts $/ \mathrm{ml}$.

Formula: This research was an experimental laboratory research with the Completely Randomize Design (CRD). The chicken grouping is based on the treatment given, namely:

Treatment 0: As a control, oocysts were not soaked in formalin

Treatment I: E. tenella was soaked in formalin with a concentration of $0.15 \%$

Treatment II: E. tenella was soaked in formalin with a concentration of $0.3 \%$

Treatment III: E. tenella was soaked in formalin with a concentration of $0.6 \%$

Treatment IV: $E$. tenella was soaked in formalin with a concentration of $1.2 \%$

After E. tenella was soaked, then chicken were inoculated as many as 10,000 oocysts orally. After 14 days, a challenging test was carried out by re-inoculating E. tenella without immersing 15,000 formaldehyde as a formalin.

Chicken and Eimeria tenella infections: Twenty-five 21-day old chickens were inoculated with 10,000 E. tenella oocysts that were patented using formalin with various levels of concentration $(0.15 \%, 0.3 \%, 0.6 \%$ and $1.2 \%)$ for 96 hours. Chickens were inoculated using $E$. tenella orally which had been washed using distilled water and centrifuged at a speed of $1500 \mathrm{rpm}$ for 10 minutes at five times. After two weeks, twenty-five 34-day-old chickens were re-inoculated with 15,000 E. tenella oocysts without formaldehyde immersion. Chicken is inoculated with E. tenella orally.

Cecum Lesion Scoring: Scoring of cecal lesions was carried out on the fifth day after inoculation, 
macroscopically. The cecal abnormalities were recorded and the degree of damage to the mucosal surface of the chicken cecum was calculated based on a score of $0-4^{14}$.

Histopathology observation: Histopathology observation was carried out at the Pathology Laboratory of the Faculty of Veterinary Medicine, Universitas Airlangga, Surabaya, Indonesia. Microscopic examination was carried out based on the histopathological changes that occurred in the cecum which had previously been made histopathological preparations, assessed by scoring seen based on the Goodwin method ${ }^{15}$.

Challenge Test: The challenge test was carried out 14 days after the first E. tenella inoculation, E. tenella which was soaked with various formalin concentrations. The challenge test was carried out by re-inoculating $E$. tenella without immersing as much as 15,000 oocysts formally. The indicator that shows the success of protective immunity is the reduced scoring of cecum lesions observed macroscopically and microscopically.

Data Analysis: Data to be obtained was macroscopic lesion scoring and microscopic lesion scoring. Data were arranged in table form using Kruskal Wallis analysis, if there are differences data, then proceed with the Mann Whitney test.

\section{Results}

\section{Macroscopic Scores of Chicken Fecal Lesions}

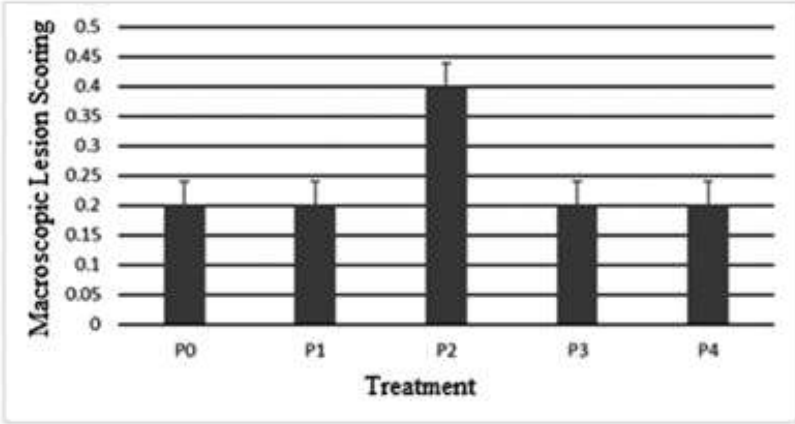

Figure 1: Macroscopic score of Chicken Fecal Lesions

The figure above is a comparison of the scores of chicken cecal lesions macroscopically after being challenged with E. tenella infective in each group of chickens with a dose of $15 \times 103$ oocyst E. tenella. Each shows mean $\pm \mathrm{SD}(\mathrm{N}=5)$. NS, not significantly different; *, $\mathrm{p}<0,05$.

\section{Macroscopic description of chicken serum}
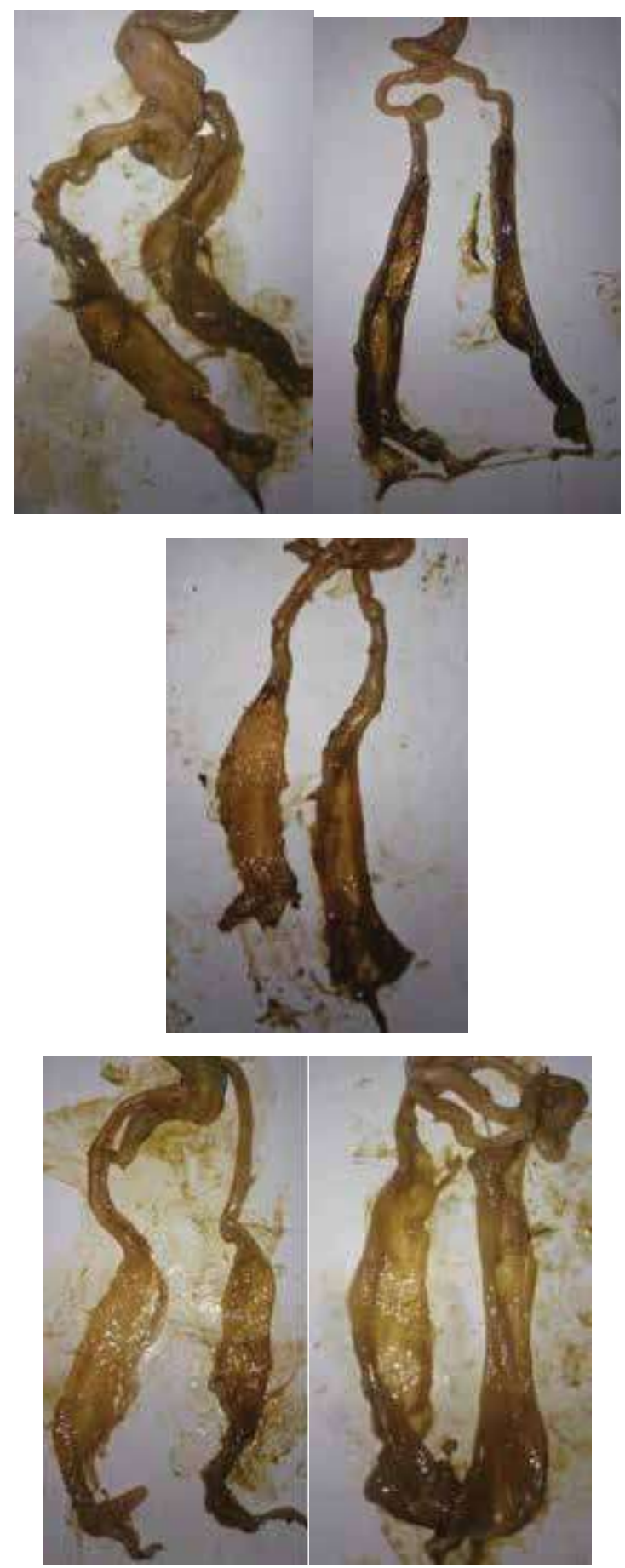

Figure 2: Macroscopic description of chicken cecum

The figure above is a macroscopic picture of chicken cecum which has been challenged by inoculating $E$. tenella infective in each group of chickens with a dose of $15 \times 103$ oocyst $E$. tenella. The intensity of petechiae is reduced by E. tenella infection which is soaked in formalin with higher concentration. A small circle shows bleeding in the cecal mucosa, the arrow shows thickening of the cecum wall. 
Microscopic score of Chicken Fecal Lesions

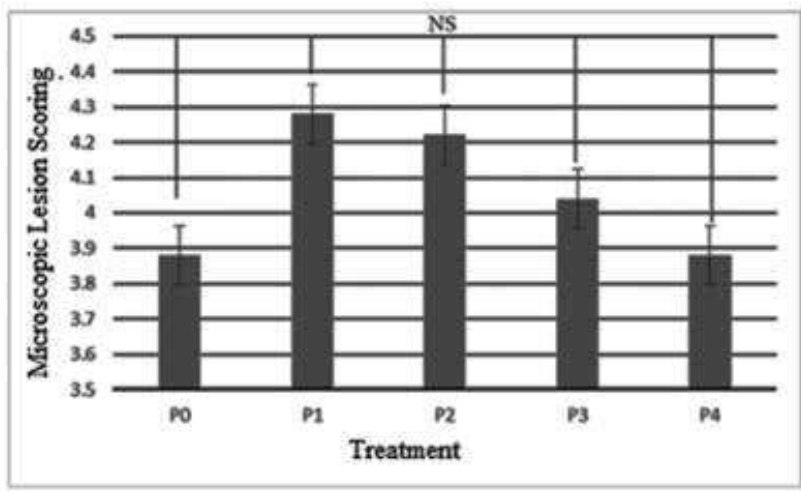

Figure 3: Cecum lesion microscopically in chickens

Figure 3 is a comparison of the scores of chicken cecal lesions macroscopically after being challenged with $E$. tenella infective in each group of chickens with a dose of $15 \times 103$ oocyst E. tenella. Each shows mean $\pm \mathrm{SD}(\mathrm{N}=5)$. NS, not significantly different; ${ }^{*}, \mathrm{p}<0.05$.

\section{Microscopic description of chicken serum}
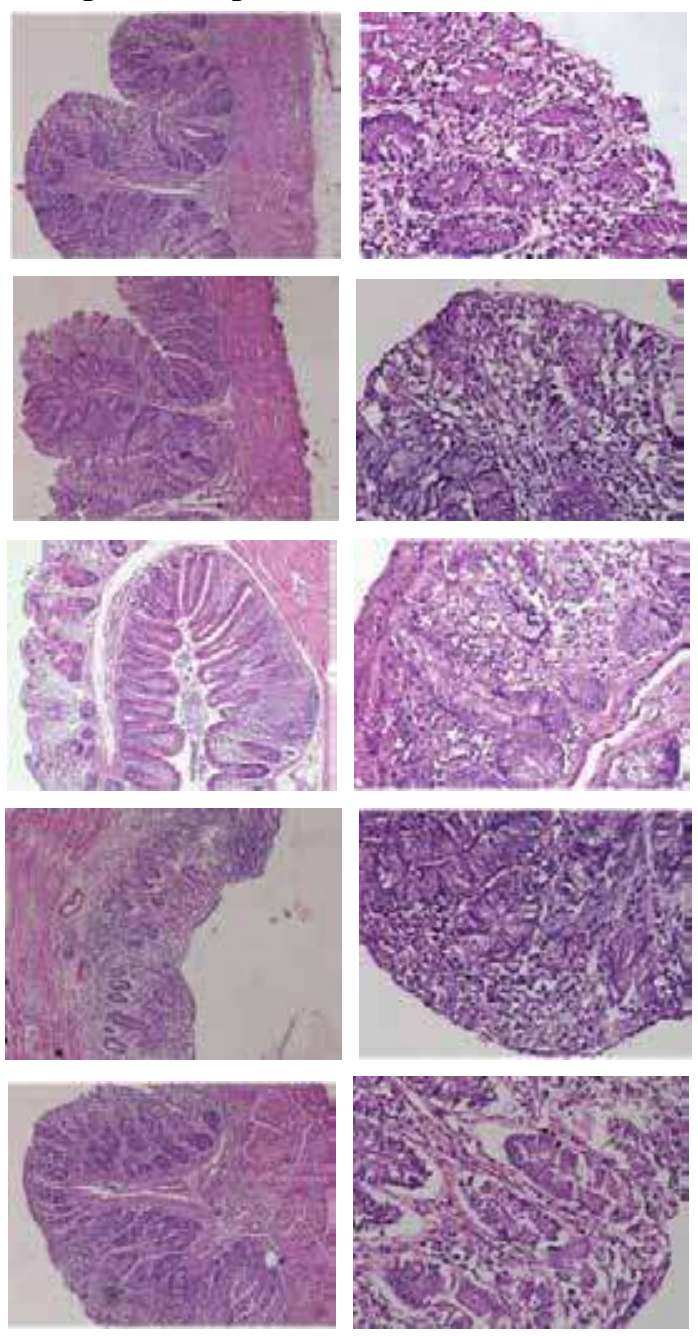

Figure 4: Microscopic description of chicken cecum
Microscopic description of chicken cecum which have been challenged by inoculating $E$. tenella infective in each group of chickens with a dose of $15 \times 103$ oocyst E. tenella with various magnifications (A (100x) and B (400x)). The small circle shows the Eimeria distribution in the cecum and the black line shows the cecum mucosa.

\section{Discussion}

Macroscopic description of chicken cecum: From the macroscopic observation of the cecum, data were obtained based on histopathological abnormalities assessed based on a score of $0-4^{14}$. At P0 it shows a normal condition because there is no damage to the caecal lesions macroscopically and there is no thickening of the cecum wall. P1 shows the degree of damage to mild level cecal lesions, characterized by bleeding spots (ptechie) that spread on the surface of the mucosal mucosa with slight changes in the color of the wall or the contents of the digestive tract. P2 shows the degree of damage to moderate cecal lesions, characterized by more bleeding and lesions with a slight thickening of the cecum wall. P3 shows the degree of damage to mild cecal lesions, there are several bleeding spots that spread to the mucosal surface of the cecum with slight changes in the color of the wall or the contents of the digestive tract. $\mathrm{P} 4$ shows a normal condition because macroscopically there is no damage to cecum lesions and there is no thickening of the cecum wall ${ }^{14}$. These changes are due to the administration of E. tenella infective oocysts when the challenge test has no effect on cecal damage macroscopically, which means that the administration of oocysts that have been soaked in formalin before the challenge test can induce protective immunity seen macroscopically from chicken cecum.

The results of the statistical analysis using the Kruskal Wallis test also did not show significant differences in each treatment. It can be explained that macroscopically, the challenging test by inoculating as many as $15,000 \mathrm{E}$. tenella infective oocysts did not affect the damage to the cecum which had been inoculated with $E$. tenella with soaking various formalin concentrations $(0.3 \%, 0.6 \%$, $0.9 \%, 1.2 \%)$. So it can be concluded that immersion of E. tenella in various concentrations of formaldehyde can induce protective immunity seen from the results of scoring and the results of macroscopic examination statistics after the challenge test which shows the results are not significantly different. The optimal formalin 
concentration in patenting E. tenella is $1.2 \%$ indicating a normal state because macroscopically there is no damage to cecum lesions and there is no thickening of the cecum wall ${ }^{14}$.

\section{Microscopic description of chicken cecum:}

Histopathological observations on cecum, data obtained based on histopathological abnormalities contained in the preparations were assessed by scores seen based on summations of $\mathrm{A}$ and $\mathrm{B}$, where $\mathrm{A}$ represents the distribution of $E$. tenella development stages found throughout the caecum, while B represents the severity of damage caused by E. tenella ${ }^{15}$.

The results of statistical analysis using the Kruskal Wallis test showed no significant differences in microscopic examination. The results obtained by histopathological preparations showed no significant differences in each treatment with the average scale which tended to be the same, namely P0: 3.88, P1: 4.28, P2: 4.22, P3: 4.04 and P4: 3.88. There are three immunity to $\mathrm{E}$. tenella, which are totally invulnerable to parasites and do not develop parasites, chicken is immune to a certain degree, where oocysts are able to complete the life cycle but no lesions occur in the intestine, and chickens show no clinical symptoms but lesions occur in intestine ${ }^{16}$.

The microscopic scoring value in figure P0 did not experience abnormalities in cecum histopathology. Microscopic observations showed normal intestinal cells, the intestinal epithelium looked compact and did not show any rupture in the cecum villi. The first infected chicken, Schizont will develop properly due to immunity to E. tenella infection is still in the process of initiation, causing damage to the cecum.

The results of the $\mathrm{P} 1$ scoring data indicate histopathological abnormalities with moderate degrees of damage to the mucosal cecum. The cecal epithelium is compact and there are several villous ruptures. When compared with P0, P1 has a higher cecum damage. This is because previously chickens were inoculated with E. tenella which was soaked in formaldehyde with low concentration so it was suspected that schizont could still damage the caecum. Tissue damage to the cecum is caused by the outbreak of the schizont stage which has three generations before entering the gamete stage. P2 shows histopathological abnormalities with mild degrees of damage to the mucosal cecum. The cecal epithelium appears compact and only a few villi rupture, when it compared with P0, P2 suffers more damage, it suspected that $\mathrm{P} 2$ has a low immune system that is lowered by its parent.

At P3 it showed almost no abnormalities in the histopathology of the cecum, the cecal epithelium appeared to be compact and rarely found in ruptured cecum villi. If vaccines are used to better control disease in an animal population and not individually, the concept of group immunity should be considered. If group immunity is carried out by reducing the likelihood of sensitive animals meeting the infected, there will be no spread of disease ${ }^{13}$. In P4 there is no abnormality in the histopathology of cecum. Microscopic observations showed normal intestinal cells, the intestinal epithelium appeared to be compact and did not show any rupture in the cecum villi and rarely found in the development of parasites.

\section{Conclusion}

Attenuation of Eimeria tenella through immersion in various concentrations of formalin $(0.15 \% ; 0.3 \%$; $0.6 \% ; 1.2 \%$ ) can induce protective immunity in terms of macroscopic and microscopic images of the cecum. The most potential formalin concentration for patenting Eimeria tenella in induces protective immunity serum in terms of macroscopic and microscopic images of cecum is $1.2 \%$. Macroscopically there is no damage to cecal lesions and no cecum wall thickening. Whereas microscopically shows the intestinal epithelium looks compact and there is no rupture in the cecum villi.

Ethical Clearance: The research process involves participants in the survey using a questionnaire that was accordant with the ethical research principle based on the regulation of research ethic committee. The present study was carried out in accordance with the research principles. This study implemented the basic principle ethics of respect, beneficence, non-maleficence, and justice.

Conflict of Interest: The author reports no conflict of interest of this work.

Source of Funding: This study is done with individual funding. 


\section{REFERENCES}

1. Allen PC, Fetterer RH. Recent Advances in Biology and Immunobiology of Eimeria Species and in Diagnosis and Control of Infection with These Coccidian Parasites of Poultry. Clin Microbiol Rev [Internet]. 2002 Jan 1;15(1):5865. Available from: http://cmr.asm.org/cgi/ doi/10.1128/CMR.15.1.58-65.2002

2. Calnek B. W, Barnes H. J, Beard C.W, Mc Dougald L.R SYM. Disease of Poultry. 10th ed. Iowa State University Press. USA; 2001. 865-867 p.

3. Min WG, Dalloul RA, Lillehoj HS. Application of biotechnological tools for coccidia vaccine development. J Vet Sci. 2004;5(4):279-88.

4. Jordan F, Pattison MA, Faragher T. Poultry Diseases. 5" Edition. WB Saunders. London; 2001.

5. Alberta C. Coccidiosis in chickens, Agriculture and Rural Development,. Agdex; 2001. 663-665 p.

6. Lillehoj HS, Lillehoj EP. Avian coccidiosis. A review of acquired intestinal immunity and vaccination strategies. Avian Dis. 2000;408-25.

7. Lillehoj H, Okamura M. Host immunity and vaccine development to coccidia and Salmonella infections in chickens. J Poult Sci. 2003;40(3):151-93.

8. Ding X, Lillehoj HS, Dalloul RA, Min W, Sato T, Yasuda A, et al. In ovo vaccination with the Eimeria tenella EtMIC2 gene induces protective immunity against coccidiosis. Vaccine. 2005;23(28):3733-40.

9. Jang SI, Lillehoj HS, Lee SH, Lee KW, Park MS, Bauchan GR, et al. Immunoenhancing effects of Montanide ${ }^{\mathrm{TM}}$ ISA oil-based adjuvants on recombinant coccidia antigen vaccination against Eimeria acervulina infection. Vet Parasitol. 2010;172(3-4):221-8.

10. Shirley MW, Bushell AC, Bushell JE, McDonald V, Roberts B. A live attenuated vaccine for the control of avian coccidiosis: trials in broiler breeders and replacement layer flocks in the United Kingdom. Vet Rec. 1995;137(18):453-7.

11. Shierly MW. Biological principle of lives, attenuated vaccines. Magy Allatorvosak Lapja. 1996;51(1):23-9.

12. Yunus M, Suprihati E. Potency of Attenuated Eimeria tenella in Protective Immunity Induction on Homologous and Heterologous Challenges. Procedia Chem. 2016;18:218-24.

13. Tizard IR. Veterinary Immunology: An Introduction. 7th ed. USA: Saunders; 2004.

14. Raman M, Banu SS, Gomathinayagam S, Raj GD. Lesion scoring technique for assessing the virulence and pathogenicity of Indian field isolates of avian Eimeria species. Vet Arh. 2011;81(2):259-71.

15. A. Goodwin M, Brown J, I. Bounous D. Use of microscopic lesion scores, gross lesion scores and oocyst count scores to detect Eimeria maxima in chickens. Vol. 27, Avian pathology : journal of the W.V.P.A. 2012. 405-408 p.

16. Long PL, Johnson J, Wyatt RD. Eimeria tenella: clinical effects in partially immune and susceptible chickens. Poult Sci. 1980;59(10):2221-4. 